\title{
COSTA RICA'S PERSPECTIVE ON TOTAL OFFICIAL SUPPORT FOR SUSTAINABLE DEVELOPMENT (TOSSD)
}

Marisa Berbegal-Ibáñez, Juan Casado-Asensio, Friederike Ruhmann, Aussama Bejraoui, Guillaume Delalande and Julia Benn
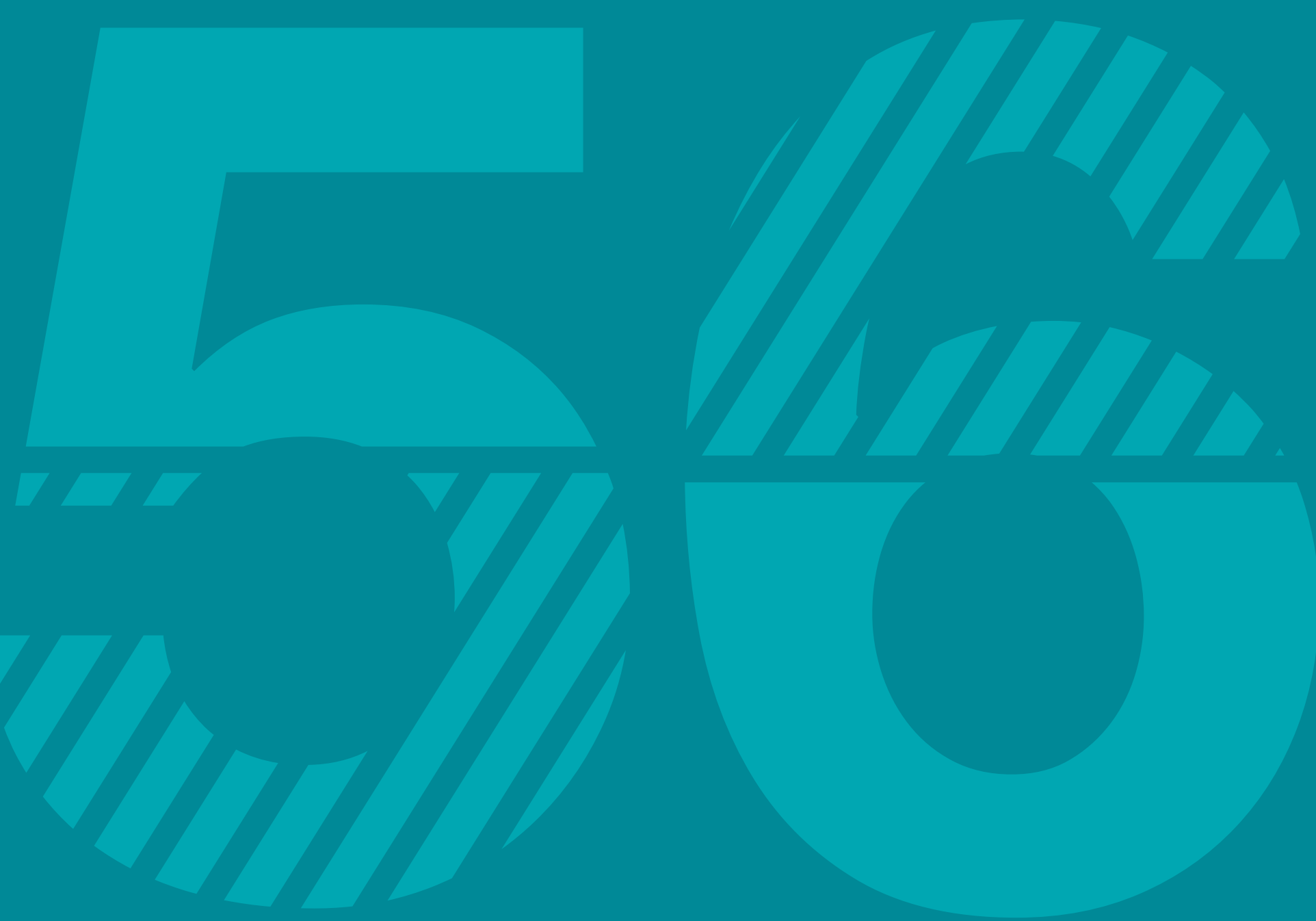

\section{OECD DEVELOPMENT CO-OPERATION WORKING PAPER 56}

Authorised for publication by Jorge Moreira da Silva, Director, Development Co-operation Directorate 



\section{Table of contents}

Acknowledgements ................................................................................................................................... 5

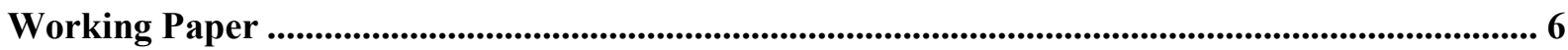

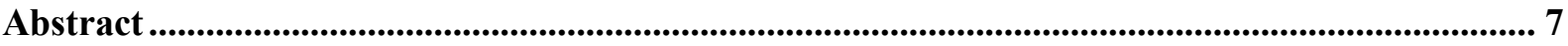

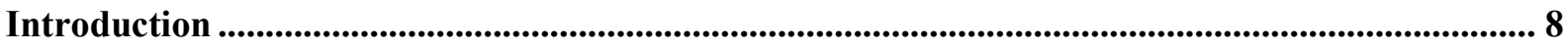

Part I. Main findings and recommendations. ........................................................................................... 9

1. Main findings of the pilot......................................................................................................................... 10

2. The usefulness of TOSSD from Costa Rica's perspective....................................................... 14

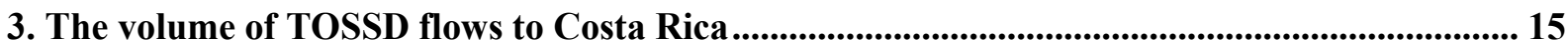

4. Recommendations to Costa Rica on the collection, collation and dissemination of

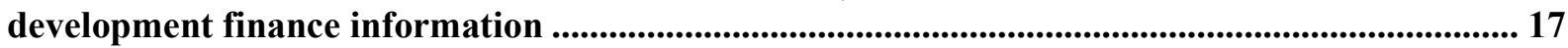

Part II. Information on TOSSD pilot studies and the context of Costa Rica................................... 20

1. Context and objectives of the country pilot study ................................................................................ 21

2. Costa Rica's economic and financing landscape ................................................................. 24

Part III. Costa Rica's perspective on the emerging Reporting Instructions.................................. 29

1. Preamble to the Reporting Instructions, main concepts and definitions ........................................ 30

2. TOSSD pillar 1: cross-border resource flows in support of sustainable development .............. 38

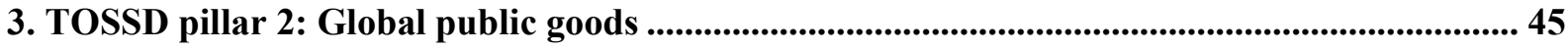

4. Reporting format, reporting cycle and detailed reporting instructions ........................................ 46

Part IV. Costa Rica's perspective as a provider of development co-operation.............................. 49

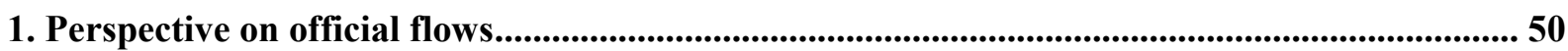

2. Perspective on other cross-border flows that could be included as "satellite indicators": private investment, private philanthropy and remittances ..............................................................52

Part V. Capacity assessment of the government of Costa Rica to access, collate, analyse and use official and private external flows ....................................................................................................... 53

1. Overview of the legal institutional architecture for development finance data ..........................55

2. Assessment of the capacity of the government of Costa Rica to manage development

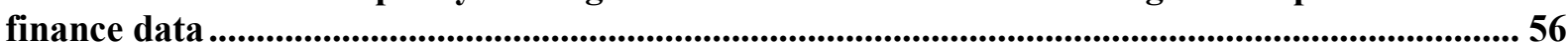

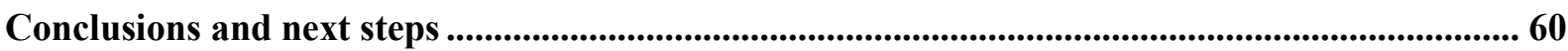

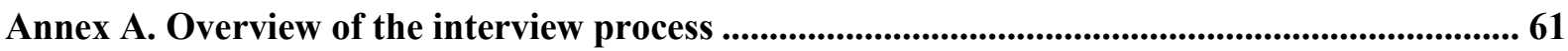

Annex B. Guide to determining the value of institutional counterpart funds in international

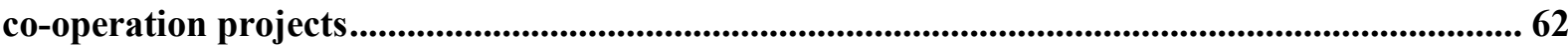

Annex C. List of institutions interviewed for the pilot TOSSD in Costa Rica ................................ 70

Annex D. Estimation of flows of Costa Rica as a provider ............................................................ 71 


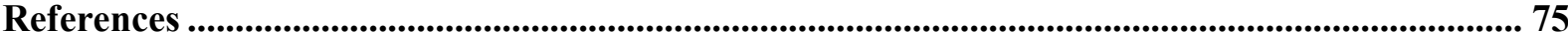

\section{Tables}

Table 1. Magnitude of TOSSD flows to Costa Rica, USD million disbursements .............................. 15

Table 2. Official development finance and officially supported export credits to Costa Rica................ 26

Table 3. Estimates of resources mobilised from the private sector through external official interventions in Costa Rica, by provider and leveraging mechanism ........................................ 44

Table 4. Estimates of resources mobilised from the private sector through external official interventions in Costa Rica, by year and leveraging mechanism ................................................ 44

Table 5. Estimates of resources mobilised from the private sector through external official interventions in Costa Rica, by sector and leveraging mechanism .............................................. 44

\section{Figures}

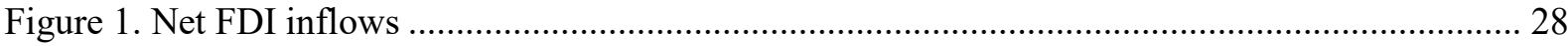

Figure 2. The two-pillar TOSSD statistical measurement framework .................................................... 34

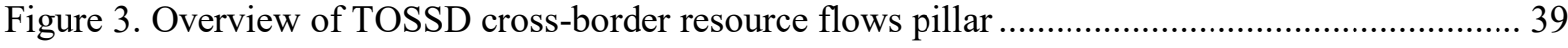

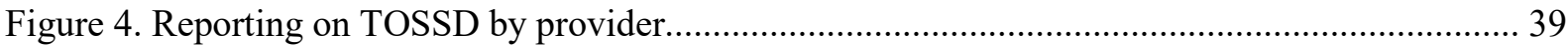

Figure 5. Examples of development enablers and global challenges ................................................ 45

Figure 6. Activity-level reporting form for TOSSD cross-border flows to developing countries.......... 48

Figure 7. Example of a complex financing arrangement: the project for a passenger train ................. 52

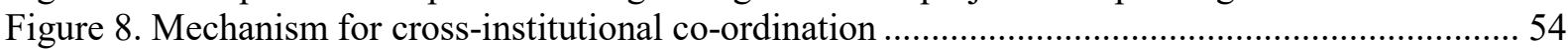

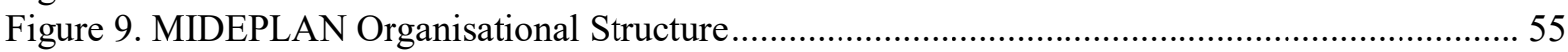

\section{Boxes}

Box 1. The Biodiversity Finance Initiative (BIOFIN) 


\section{Acknowledgements}

The authors (Marisa Berbegal-Ibanez, Juan Casado-Asensio, Friederike Ruhmann, Aussama Bejraoui, Guillaume Delalande and Julia Benn) would like to thank the Government of Costa Rica and particularly the International Co-operation Directorate of the Ministry of National Planning and Economic Policy (MIDEPLAN) for organising and co-ordinating the country pilot study, as well as reviewing previous versions of this report. Costa Rica's valuable contribution helped to offer optimal conditions for carrying out this pilot study.

The Secretariat would also like to thank all staff of the institutions (mentioned in Annex C) who came to meetings during the in-country mission for their valuable time.

Moreover, the authors would like to thank Ms Emily Bosch and Ms Stacey Bradbury for reviewing the paper and providing very useful comments.

Finally, the authors would like to thank the European Union for the financial support that made this Costa Rican pilot study possible, which provides vital information for the work of the international TOSSD Task Force and the possibility of testing the various TOSSD parameters and methodologies.

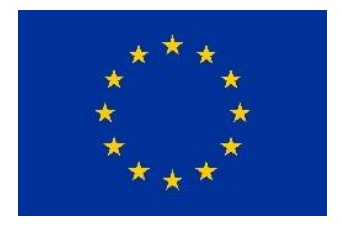

Co-funded by

the European Union 


\section{Working Paper}

OECD Working Papers do not represent the official views of the OECD or of its member countries. The opinions expressed and arguments employed are those of the author(s).

Working Papers describe preliminary results or research in progress by the author(s) and are published to stimulate discussion on a broad range of issues on which the OECD works. Comments on this Working Paper are welcome and may be sent to dac.contact@oecd.org - Development Co-ordination Directorate, OECD, 2 rue André-Pascal, 75775 Paris Cedex 16, France.

This document, as well as any data and any map included herein, are without prejudice to the status of or sovereignty over any territory, to the delimitation of international frontiers and boundaries and to the name of any territory, city or area 


\section{Abstract}

This Working Paper summarises the main findings and recommendations of the pilot study carried out in Costa Rica as part of the development of the total official support for sustainable development (TOSSD) measurement framework. The Paper includes first approximations of TOSSD flows to Costa Rica. These flows in 2016 amount to around USD 559 million of official development finance and USD 60 million of private finance mobilised through official development interventions. These first estimations were reached using OECD DAC statistics. However, these figures are likely to be largely underestimated owing to a lack of available information, particularly concerning official support to Costa Rica from the People's Republic of China and other non-DAC providers. The pilot study also indicated that the government is able to access, collect, collate, analyse and use data on external financing to the country using national data, thanks to its institutional and IT systems. However, the legislative framework requires adjustment and there is scope for improving co-ordination in order to avoid duplication of effort. 


\section{Introduction}

This document presents the findings of the country pilot study carried out in Costa Rica on the new measurement framework of TOSSD, including the conclusions of the in-country mission carried out from 24 September to 5 October 2018.

Part I summarises the principal findings and recommendations of the pilot study, including first orders of magnitude of TOSSD flows to and from Costa Rica.

Part II provides some background on the concept of TOSSD, the objectives and methodology of the TOSSD pilot studies, and sets out Costa Rica's economic and development finance landscape.

Part III provides preliminary feedback on the emerging TOSSD Reporting Instructions, as designed by the TOSSD Task Force at the time of the mission.

Part IV provides an overview of the role of Costa Rica as a provider of development co-operation (the country has a dual role of provider and recipient of development co-operation).

Part V provides an assessment of the Government's capacity to collect, collate, use and disseminate information on official and officially supported private development finance in Costa Rica. 


\section{Part I. Main findings and recommendations.}

This part of the report presents the main findings that emerged from interviews with the Costa Rican administration on total official support for sustainable development (TOSSD). TOSSD is a statistical framework currently being developed to capture resources in support of the sustainable development goals. It is composed of two pillars tracking officially supported (i) cross-border or external flows to developing countries and (ii) finance for promoting development enablers and addressing global challenges at regional and global levels (the global public goods agenda).

The main objective of the TOSSD pilot studies is to identify how TOSSD can take into account the perspective of developing countries and meet their development financing information needs. They also serve to test the statistical methodology in the particular context of countries and make any adjustments of the TOSSD methodology if needed. Costa Rica was selected to conduct a pilot study because it is actively involved in the development of TOSSD and because it is a leading country with regard to its model of sustainable development. 


\section{Main findings of the pillot}

Costa Rica supports most of the TOSSD concepts and classifications included in the Reporting Instructions, including the TOSSD definition and approach to sustainable development. However, the two-pillar TOSSD approach caused some confusion. The Costa Rican administration has made the following suggestions:

- There is broad agreement with regard to the concept of sustainable development. Implementation of this concept by Costa Rica is strict and based on alignment with the National Development Plan, under which the greatest priority is environment. This is because the environment is the greatest source of national wealth. Thus, some of the officials interviewed regard the operational definition of sustainable development in the TOSSD framework as very broad. The new planning document, the National Development and Public Investment Plan, is consistent with the goals and objectives of the 2030 Agenda for Sustainable Development. There is also general agreement that TOSSD should be updated as and when a post 2030 Agenda for Sustainable Development has been agreed.

- There is general agreement with the definition of "resource flows", with special emphasis on the importance that flows of in-kind technical and financial co-operation have for Costa Rica. Technical co-operation is interpreted broadly to include training, the sharing of experience, knowledge, technology and awareness-raising activities.

- There was agreement on the definition of "officially supported". No one was able to provide an example of a business "under significant government influence" (where the States owns between 10 and $50 \%$ of shares) and the various stakeholders confirmed that public businesses in Costa Rica are fully publicly owned.

- There is linguistic confusion over the first pillar, because "cross-border co-operation" refers to co-operation between countries that share a border in Spanish. The proposal was to replace "cross-border flows" with "external flows". The English concept was clear however. There was also some conceptual confusion concerning the second pillar. This pillar will be developed at forthcoming TOSSD Task Force meetings.

- Many of the activities that take place in Costa Rica that refer to the management of protected areas or natural resources have spillover effects in other countries in the region. Therefore, the proposal is to include either a third regional pillar, or to disaggregate the second pillar by region. As a small country, Costa Rica is more inter-dependent with the Central American region than with Latin America and the Caribbean, and thus proposes that sub-regions should be established and the continent should not be viewed as a single entity. For other matters (for example migration), it could be included within the region of Latin America.

- Costa Rica proposes adding a third category to paragraph 24 of the Reporting Instructions (which explains the concept of provider and recipient), namely a "dual country", i.e. a country that is both a provider (provides in-kind South-South and triangular co-operation, makes contributions to international bodies including peacekeeping bodies, provides humanitarian aid and care for migrants and refugees) and a recipient. TOSSD should collate data from providers and dual 
countries. Costa Rica would also be prepared to report data on in-flows in order to make it possible to triangulate information with providers, but this would require setting up a mechanism to reconcile data in the event of discrepancies - otherwise this would prove to be an onerous task for the Secretariat.

- As a provider, Costa Rica would be capable of providing a partial report on TOSSD as of 2019. In order to report on all flows, it would have to increase its capacity, amend the legislative and political framework, and improve in-country co-ordination.

- There is agreement on including debt relief among cross-border flows. Costa Rica is not currently part of any debt-relief process, but, in the past, has taken part in a debt-for-environmental-projects swap.

- Costa Rica does not collect data on private funds mobilised from the private sector.

- Costa Rica does not have a strategy to provide contributions to multilateral bodies. The bulk of its contributions are compulsory, and, in any event, the decision on which thematic bodies the country will join is delegated to the various ministries and there is no co-ordination or oversight. In most cases, decisions are a response to economic criteria.

- Officials considered that short-term contributions should be included in TOSSD. For the most part, these are flows that contribute to general business operations, affecting economic well-being and employment. It would make no difference whether they come from a multilateral development bank or a bilateral financial institution. The data on short-term finance are collected by the Central Bank.

- Costa Rica regards it as important for TOSSD to be linked to the SDG targets (a link with the goals would be too vague). The Technical Secretariat at MIDEPLAN is responsible for defining the national SDGs agenda, which also takes a targetbased approach. TOSSD could supply information for the National Development Plan by identifying external resources to Costa Rica by SDG target.

- Costa Rica takes a very positive view of the fact that countries can voluntarily opt in to the list of TOSSD-eligible countries. If they graduate from Official Development Assistance, there would be no objection to opting into TOSSD in order to secure a genuine, effective transition backed by specific and appropriate co-operation mechanisms to make the transition achievable.

- Costa Rica has recently drawn up a methodology to quantify technical co-operation in terms both of the co-operation provided and of the national counterpart funds that it makes available for projects where it is a recipient. The methodology quantifies costs, but also includes a very innovative aspect estimating the value of knowledge and experience acquired over an official's or expert's career in the area in question. The country has not previously quantified technical co-operation in cash terms and expects to do so from 2019 onwards.

- Concerning the structure of governance of TOSSD, there is general agreement in tying the concept to the highest level of governance in the United Nations system. If a regional data-collection system were to be established (which is viewed positively by Costa Rica), the institution with the capacity to collect those data would be the Economic Commission for Latin America and the Caribbean 
(ECLAC). ECLAC includes the SCA (Statistical Conference of the Americas), which is currently studying SDG indicators.

- MIDEPLAN maintains the SIGECI system to report on non-reimbursable cooperation. There are three databases for investment: DELPHOS, SYGADE (External Debt Management System) and a third database held by the Central Bank. The DELPHOS database is managed by MIDEPLAN, and SYGADE by the Ministry of Finance. These public investment databases are incompatible and generate duplicate records. In addition, they are incomplete.

- Suggestions for additional fields in the TOSSD reporting format are as follows:

- National counterpart funding for development projects, including financial counterpart funding and the monetary value of technical counterpart provision; this would increase the visibility of the efforts made by TOSSD recipients towards development;

- Geographical location of the projects (voluntary basis);

- The administrative expenditure by provider for each project;

- A clearer definition of the channel used or the establishment of two subcategories - as the current definition is difficult to apply to some projects because the entity administering the funds is not necessarily the implementing entity; and

- Two forms of South-South co-operation: traditional and bi-directional (whereby both partners benefit from the South-South exchange).

- As a country with a dual role, Costa Rica would be prepared and able to report under TOSSD:

- Contributions to multilateral bodies made by the Ministry of Finance, although they are not deemed by Costa Rica as development co-operation flows. However, they would be prepared to report these flows for comparability purposes with an explanation in the metadata;

- In-kind technical (South-South and triangular) co-operation;

- Contributions to peace-keeping operations;

- Aid to refugees and migrants in Costa Rica; in principle, it would be difficult to disaggregate the two concepts;

- Humanitarian aid, although it was not possible to interview the responsible unit in this area;

- Research into development issues conducted by public universities in the event that the law is changed or an arrangement is made with the universities that were not interviewed as part of this report;

- Operational administrative expenditure of MIDEPLAN and other staff with responsibility for development co-operation.

- Both as a provider and a recipient, Costa Rica has the necessary capacity to manage development finance information, but needs changes in legislation and institutions in order to be able to report all grants and technical co-operation. Support from cooperation partners would be welcome with a view to strengthening and establishing 
a single data collection system that draws on the various existing databases as well as future databases set up at MIDEPLAN (see part V for a light capacity assessment of the capacity of the government to manage development co-operation data).

- Regarding flows beyond TOSSD, the Central Bank collates information on foreign direct investment (FDI) and, to a certain extent, on philanthropic grants and migrants' remittances. Remittances are estimated using surveys. Where direct investment is concerned, CINDE (Costa Rican Investment Promotion Agency) and institutions linked to the Ministry of Foreign Trade are working to ensure that investment aligns with the sustainability aspects of the National Development Plan, notably in environmental sustainability. There is no alignment policy for philanthropic grants or remittances.

- Until recently, there was no legal framework governing public private partnerships (PPPs). Two decrees have recently been published to regulate PPPs and PPPs for Development (PPPDs). It is assumed that use of these vehicles will increase and that more information will be available about them. It would therefore be appropriate to work with the CNC (Costa Rican National Concessions Council) to collect this information in MIDEPLAN's Public Investments Project Data Bank and thereby capture data on both public and private investment. 


\section{The usefulness of TOSSD from Costa Rica's perspective}

TOSSD data would be used primarily by MIDEPLAN. They may also be of use to the Ministries of Foreign Affairs and of Finance, the Office of the Controller-General and the Office of the President, as an approach to open government. In particular, TOSSD could prove useful in terms of:

\section{Development planning:}

- Identifying financing needs for the 2030 Agenda. In that regard, it is likely to be useful to the extent that there is a direct relation to the targets.

- Facilitating planning for development co-operation and investment in the medium and long term by including information on commitments that are not currently collected in SIGECI.

- Understanding how development co-operation aligns with the national strategy for sustainable development.

\section{Transparency of information and monitoring:}

- Increasing transparency and accountability in the country as well as helping to monitor and support the evaluation function of development co-operation policy.

- Accessing information on investments or flows of resources directed towards Costa Rica and comparing them with flows directed towards other countries in the region.

- Identifying how funding gaps are being filled in other countries to inform national fiscal policy decision-making (national accounting and budgeting processes).

- Increasing visibility of Costa Rica's sustainability agenda, which could attract additional funds.

- Triangulating information on available sustainable development funding to the government, although it has been acknowledged that the task of reconciling differences would be complex and that it would be necessary to build capacity for the reconciliation process.

- Establishing a system of collecting information on care services provided to migrants and refugees in order to determine how much Costa Rica is investing as a provider in terms of decision-making, accountability and transparency, as well as to reinforce planning systems.

- Providing information on the private funds that have been mobilised, which are not currently collected.

\section{International visibility of Costa Rica's efforts towards sustainable development:}

- Making national counterpart funds visible: including them in the reporting format will demonstrate to co-operation partners that, despite the fiscal crisis, the country is making a significant effort.

- Understanding which activities are implemented through NGOs and other stakeholders, because the government does not currently collect this information. 


\section{The volume of TOSSD flows to Costa Rica}

Estimated TOSSD for Costa Rica amounts to USD 499.2 million of official finance and USD 59.9 million of private finance mobilised through official interventions.

Table 1. Magnitude of TOSSD flows to Costa Rica, USD million disbursements

\begin{tabular}{|c|c|c|}
\hline Category of flow & $\begin{array}{l}\text { Estimates in USD } \\
\text { million (2016) }\end{array}$ & Notes and sources \\
\hline \multicolumn{3}{|l|}{ A. GRANTS } \\
\hline \multicolumn{3}{|c|}{ Official bilateral flows from DAC providers (excluding EU institutions) } \\
\hline $\begin{array}{l}\text { Grants (excluding technical } \\
\text { co-operation) }\end{array}$ & 23.1 & $\begin{array}{c}\text { Grants made by DAC members, }{ }^{1} \text { excluding technical co- } \\
\text { operation but including debt relief }\end{array}$ \\
\hline Technical co-operation & 10.8 & Technical co-operation provided by DAC members \\
\hline \multicolumn{3}{|c|}{ Official bilateral flows from non-DAC providers ${ }^{2}$} \\
\hline $\begin{array}{l}\text { Grants (excluding technical } \\
\text { co-operation) }\end{array}$ & 0.3 & $\begin{array}{l}\text { Grants made by non-DAC providers, excluding technical co- } \\
\text { operation }\end{array}$ \\
\hline Technical co-operation & 0 & Technical co-operation provided by non-DAC providers \\
\hline \multicolumn{3}{|c|}{ Official flows from multilateral institutions (including EU institutions) - trust funds also included } \\
\hline $\begin{array}{l}\text { Grants (excluding technical } \\
\text { co-operation) }\end{array}$ & 17.9 & Grants (excluding technical co-operation) \\
\hline Technical co-operation & 0.2 & Technical co-operation \\
\hline B. FINANCIAL TRANSACTIONS & & \\
\hline
\end{tabular}

\begin{tabular}{|c|c|c|}
\hline \multicolumn{3}{|c|}{ Official bilateral flows from DAC providers (excluding EU institutions) } \\
\hline Capital transactions & 110.7 & $\begin{array}{l}\text { Concessional and non-concessional loans, mezzanine finance } \\
\text { and equity and shares in collective investment vehicles }\end{array}$ \\
\hline \multicolumn{3}{|c|}{ Official bilateral flows from non-DAC providers } \\
\hline Capital transactions & 0 & $\begin{array}{l}\text { Concessional and non-concessional loans, mezzanine finance } \\
\text { and equity and shares in collective investment vehicles }\end{array}$ \\
\hline \multicolumn{3}{|c|}{ Official flows from multilateral institutions (including EU institutions) } \\
\hline Capital transactions & 336.2 & $\begin{array}{l}\text { Concessional and non-concessional loans, mezzanine finance } \\
\text { and equity and shares in collective investment vehicles }\end{array}$ \\
\hline Total Official Flows $(A+B)$ & 499.2 & \\
\hline \multicolumn{3}{|c|}{ C. Private finance mobilised by official interventions } \\
\hline $\begin{array}{l}\text { Private finance mobilised by } \\
\text { official development } \\
\text { interventions }\end{array}$ & 59.9 & $\begin{array}{l}\text { Based on estimates from the 2013-2015 DAC Survey on } \\
\text { Amounts Mobilised or Official Sources in Costa Rica, where } \\
\text { available. }\end{array}$ \\
\hline
\end{tabular}

Source: OECD (n.d.[1]), Creditor Reporting System, https://stats.oecd.org/ 
Discussions at expert workshops, international events and in previous pilot studies have shown that officially supported export credits and short-term finance can also support the SDGs and be included in TOSSD. The total for officially supported export credits to Costa Rica amounted to USD 6.3 million in 2016. Short-term finance information is in principle available at the Central Bank. Beyond TOSSD, Costa Rica is of the view that private flows at market terms (e.g. FDI) and charitable grants would also provide useful information on external flows to the country. 


\section{Recommendations to Costa Rica on the collection, collation and dissemination of development finance information}

- Costa Rica has a good system for collecting development co-operation information as well as a government with the capacity and the human and technical resources to carry out this work. The country has sufficient technical means such as IT equipment, databases, skilled staff, and a system for collecting information and co-ordinating processes. It has various instruments for making information accessible to the public, such as the SIGECI platform and the investment map.

- However, the country should ensure that the SIGECI system collects all nonreimbursable sustainable development resources. This involves collecting data on co-operation at regional as well as national level, together with data concerning humanitarian aid, contributions to multilateral bodies and peacekeeping operations, scholarships and training received, and aid to refugees and possibly migrants. Accordingly, all Costa Rican institutions, including autonomous and semi-autonomous entities as well as Ministries, are strongly encouraged to record their activities using the format drawn up by MIDEPLAN on a regular basis and at least once a year.

- In order to achieve that goal, a legal framework would have to be established under which the autonomous bodies, including the public universities, would be required to report their co-operation initiatives and projects. A more comprehensive information system would enable MIDEPLAN to carry out its mandate to plan more effectively, improve co-ordination with co-operation partners working in Costa Rica and provide better advice on the country's public investment needs.

- Co-ordination between stakeholders could be improved. For example, coordination between the Ministry of Foreign Affairs, which is responsible for aligning co-operation with the country's foreign policy, and MIDEPLAN, which co-ordinates the technical aspects of data and alignment with the National Development Plan, could be improved. This will ensure that all information on flows of development co-operation resources, which is channelled through the Ministry of Foreign Affairs, and data on grants received, are included in SIGECI.

- In order to avoid burdening MIDEPLAN with a workload that its current staff levels would struggle to cope with, it would be advisable to allow data to be collected on a decentralised basis under the liaison system. For example, the lead Ministries could be responsible for collecting and validating information both from their Ministries and from the autonomous bodies that report to them, and, once collated, they could send that information to MIDEPLAN for approval. This would reduce the workload, increase the information collected in SIGECI and provide two quality control mechanisms before delivering to the TOSSD Secretariat, thus improving the quality of the reporting. To that end, it would be necessary to redesign the system for co-ordinating data collection and adjust the SIGECI platform so that it is capable of implementing these changes. 
- Regarding technical co-operation, it would be advisable for institutions reporting to MIDEPLAN to collect a breakdown of officials, per diem allowances, accommodation, etc. This would, on the one hand, involve a review to ensure that the new methodology is being correctly applied and, on the other hand, enable reporting to TOSSD to be in line with the methodology adopted by the TOSSD Task Force, or allow both methodologies to be used for a trial period.

- Similarly, steps should be taken to ensure that DELPHOS, SYGADE and the Central Bank investment platform are interoperable, and that information is shared, there is no duplication of records, loss of resources or effort wasted on double counting because reporting is an additional task for Ministries. It would be advisable for the Ministry of Finance, MIDEPLAN and the Central Bank to agree on a system that can be shared across all institutions to collect the information required by both bodies in their decision-making processes. Similarly, the information should be streamlined so that incoming investment can be reported under TOSSD.

- Support from co-operation partners would be welcome in order to strengthen and establish a single data-collection system that draws on the various databases that currently exist as well as those to be established in the future.

- The DELPHOS platform could collect data on private funding leveraged in blended finance projects based on donor-provided information. It could also include information about the private funding leveraged in PPPD projects. To that end, a legal instruction to collect that information could be incorporated into the Decree on PPPDs.

- Similarly, the SIGECI and public investment databases should be compatible and ideally available for consultation from a single source in order to provide an overview and improve planning. To that end, the fields in the databases will require streamlining given that the databases have different objectives.

- Ideally, these changes should be introduced as soon as possible so that Costa Rica can begin to report its TOSSD data in the first half of 2019 .

- It would be advisable for Costa Rica to collect information on private finance in support of sustainable development, at least for public-private finance schemes. Working together with the CNC, MIDEPLAN would be capable of and willing to conduct this exercise.

- Costa Rica should seek a domestic political mandate to co-ordinate its development co-operation policy. As an upper middle-income country, Costa Rica should position itself in view of the shift in development co-operation, where providers expect countries to take a more pro-active role in managing the cooperation they provide. In respect of improvements in co-ordination, MIDEPLAN could go back to leading a donor co-ordination roundtable in order to be able to plan development co-operation and better align resources with needs.

- MIDEPLAN could work with the OECD and its member countries on development co-operation projects in order to take advantage of the technical resources and experience acquired in generating statistics, handling databases, designing and delivering bilateral and triangular projects, etc. 
- Costa Rica is a globally recognised leader in its approach to sustainable development and a staunch advocate of TOSSD. It should, at regional policy and technical levels, use its position as a leader in the field to provide information about TOSSD and its beneficial effects in terms of measuring the 2030 national agendas and boosting resources for upper middle-income countries or countries that have recently graduated from ODA. 
Part II. Information on TOSSD pilot studies and the context of Costa Rica

This part of the report briefly explains the TOSSD concept, the methodology and objectives of the TOSSD pilot studies and explains why Costa Rica represented an ideal candidate to conduct a TOSSD pilot study. 


\section{Context and objectives of the country pilot study}

\subsection{The concept of TOSSD}

Today, many developing countries are becoming less reliant on official development assistance (ODA) and are turning towards other types of official support, including nonconcessional resources and private capital, usually in co-financing arrangements with public finance. Moreover, with the increasing number of actors, a transparent and inclusive measurement framework is needed to measure total officially supported flows of external resources that support sustainable development.

The Addis Ababa Action Agenda (AAAA) called for the international community to confront the problem of financing and of creating a suitable environment for sustainable development at all levels, recognising the continued special role of official development finance and, at the same time, the need to mobilise other resources to support country development, within an inclusive and transparent consultative process.

Since the Addis Ababa Conference, the OECD has been working in consultation with the international community to develop a new measurement framework for the Sustainable Development Goals (SDGs) era called total official support for sustainable development (TOSSD). The TOSSD framework aims to provide a comprehensive picture of external official support for sustainable development and flows mobilised through official interventions, thereby facilitating a common international reporting standard for all providers of development co-operation, including emerging economies.

TOSSD is expressly designed to track resources invested to achieve sustainable development and will encompass all financing provided by official bilateral and multilateral institutions, regardless of the level of concessionality involved or instrument used. It includes both concessional and non-concessional financing provided through various instruments, e.g. grants, loans, equity and mezzanine finance, among others. It also aims to cover activities that promote and enable sustainable development, including contributions to global public goods that are relevant for development. It aims to create appropriate incentives for using international public finance and risk mitigation instruments to mobilise additional resources for development.

The TOSSD measurement framework ${ }^{3}$ is composed of two pillars tracking officially supported (i) cross-border or external flows to developing countries and (ii) finance for promoting development enablers and addressing global challenges at regional and global levels.

In the first semester of 2017, an International Task Force ${ }^{4}$ was established to carry out the technical work required to operationalise TOSSD and ensure it conforms to international statistical standards.

\footnotetext{
${ }^{3}$ For further information on TOSSD, see: http://www.oecd.org/dac/financing-sustainable-development/tossd.htm.

${ }^{4}$ For further information on the TOSSD Task Force, see: http://www.oecd.org/dac/financing-sustainabledevelopment/development-finance-standards/tossd-task-force.htm.
} 


\subsection{Engagement of partner countries and South-South co-operation providers in the TOSSD framework}

The support and engagement of developing countries and South-South co-operation providers are fundamental for TOSSD to be a viable, relevant and robust international statistical standard. The OECD already carried out three country pilot studies to gather the valuable perspectives of TOSSD recipient countries and better understand the potential of TOSSD to be a global framework. The studies took place between 2016 and 2018, before starting to develop this statistical framework (Senegal (Delalande, G. and V. Gaveau, 2018), and Philippines (Delalande, G., R. Halvorson-Quevedo and C. Sangaré, 2018), ) and during the development of the TOSSD Reporting Instructions (Nigeria, (Delalande, G., et al., 2018),). These pilots shed light on the countries' views about certain eligibility criteria (e.g. the inclusion of various costs incurred and disbursements made in provider countries) measurement approaches (e.g. use of purchasing power parities) and features required in order for the framework to inform country policy and planning needs (e.g. budgeting, balance of payments, debt sustainability). The Costa Rica pilot presented in this report is based on the draft of the TOSSD Reporting Instructions, which were developed by the international TOSSD Task Force. For the purposes of this study, the version used is 1.0, as of 12 July $2018^{5}$.

\subsection{Pilot study objectives and methodology}

The main objective of the pilot study is to identify how TOSSD can take into account the perspective of and meet the development financing information needs of Costa Rica, and to test the statistical methodology in the particular context of the country. More specifically, the study seeks to:

- Refine and test the TOSSD statistical methodology in terms of the nature of activities and the instruments to be included in the measurement framework and inform proposals for establishing TOSSD measurement boundaries as well as eligibility criteria.

- Provide estimates of TOSSD flows to and from Costa Rica.

- Carry out a light assessment of the capacity of Costa Rica to access, collate, analyse and use data on external official and private finance in support of sustainable development.

- Test the current methodologies of the international TOSSD Task Force for valuing in-kind technical co-operation.

The TOSSD Task Force is currently in the process of developing the TOSSD framework, and the pilot will seek to support the efforts of the Task Force by focusing on specific issues that are particularly relevant to Costa Rica.

The pilot study methodology consisted of three phases: (a) a desk review of existing documentation and statistics; (b) an in-country mission that took place from 24 September to 5 October 2018; and (c) the final report of the study.

\footnotetext{
${ }^{5}$ Available at http://www.oecd.org/dac/financing-sustainable-development/development-financestandards/Emerging\%20excerpts\%20of\%20TOSSD\%20Reporting\%20Instructions_as\%20of\%201 2\%20July.pdf
} 
- Desk review: The OECD conducted a statistical analysis of available data on sustainable development financing flows to and from Costa Rica, drawing on OECD data on concessional and non-concessional official resources and data from other international sources e.g. World Bank, IMF, UNCTAD, sources of private banking and business data, etc. An analysis of key country data on sustainable development financing was also carried out, including the Costa Rican National Development Plan, budget and economic planning documents, other documents, the results of Paris Declaration and Busan monitoring exercises, assessments and analyses by international financing institutions. Regarding the Costa Rican capacity assessment component, the desk review looked at the extent to which Costa Rica produces information on external official finance inflows. The desk review also enabled the methodology and specific objectives for the pilot to be refined.

- In-country mission: The in-country mission included a series of interviews ${ }^{6}$ to gather the viewpoints of a wide range of stakeholders about the objectives and scope of TOSSD, its core features and statistical parameters. Two OECD experts ${ }^{7}$ visited Costa Rica between 24 September and 5 October 2018. The Costa Rican government organised the mission's agenda and interviews with the relevant stakeholders.

- The final report, which is the present document.

\subsection{Costa Rica: an ideal candidate for a pilot study on TOSSD}

Costa Rica represented an ideal candidate for hosting a TOSSD pilot study. First, Costa Rica is an active member of the International TOSSD Task Force ${ }^{8}$ set up to develop TOSSD. Costa Rica possesses $6 \%$ of global biodiversity and is committed to sustainable development, as reflected in its National Development Plan and its intention, for example, to become a carbon neutral country by 2021. It has also been pioneering implementation of the 2030 Agenda and is the first country in the world to sign a National Pact for delivering the SDGs. ${ }^{9}$ A recent OECD survey showed that Costa Rica is the seventh largest recipient of private finance mobilised in Latin America through official development interventions (Benn et al. 2017). Costa Rica also possesses considerable experience in providing co-operation to other countries, notably through its Ministry of National Planning and Economic Policy (MIDEPLAN). Furthermore, it should be noted that Costa Rica is an upper middle-income country but nonetheless has significant financing and structural development challenges (ECLAC 2016). Costa Rica is also seen as playing the dual role of development co-operation recipient and technical assistance provider.

\footnotetext{
${ }^{6}$ See Annex C for the full list of institutions visited during the mission to Costa Rica.

${ }^{7}$ Marisa Berbegal-Ibañez, Statistical Policy Analyst, DCD/FSD, Marisa.Berbegallbanez@oecd.org and Juan CasadoAsensio, Policy Analyst, DCD/FOR, Juan.CasadoAsensio@oecd.org.

8 It organised the Second Meeting of the TOSSD Task Force in San José in December 2017 and took part in various TOSSD dissemination events, including events at the UN Statistical Commission or in the Financing for Development Forum in 2018.

${ }^{9}$ See, for example, https://undg.org/silofighters blog/new-voices-to-build-costa-ricas-future.
} 


\section{Costa Rica's economic and financing landscape}

\subsection{Overall economic and development situation}

Costa Rica is one of the oldest democracies in Latin America. It has managed to maintain a stable political system over the years. According to the OECD Economic Survey of Costa Rica in 2018, its consistent economic, social and environmental progress has contributed to this outcome. With a population of 5 million as of 30 June 2018, the country scores above average on the OECD Better Life Index (OECD 2016). It is a global leader in terms of biodiversity and has accomplished much in terms of its environmental policies; for example, it is the only tropical country in the world that has reversed deforestation (World Bank, 2018). Categorised as an upper middle-income country, Costa Rica has shown steady economic growth over the past 25 years. Costa Rica has improved living standards, increased its use of sustainable natural resources and managed to double its per capita GDP over the past three decades (OECD 2018). Costa Rica's GDP per capita currently stands at USD 10830 (2016) with its total GDP standing at USD 56989 billion in 2016 (World Bank 2018). Costa Rica ranks 66th of 188 on the Human Development Index (Country Economy, 2015), a higher rating than that of other countries in the region. Costa Rica is an OECD accession candidate and is working towards adopting the recommendations of the OECD Economic Survey 2016 (OECD 2018)

Inflation is returning towards the Central Bank target, and the external current account deficit is narrowing. However, Costa Rica's fiscal deficit means that the country is vulnerable to changes in global financial conditions, and fiscal reform is needed. If fiscal vulnerabilities are not tackled, Costa Rica's competitiveness and external position could be compromised (IMF, 2018). Although Costa Rica has reduced its poverty levels, inequalities persist, which could be partly due to the taxation structure, which hinders the redistribution of incomes through government programmes (ECLAC, 2016). In addition to these structural gaps, Costa Rica is facing other challenges. This includes a high rate of unemployment (9.5\% in 2016) (IMF, 2018) mainly affecting low-skilled young people, rapidly growing public debt (IMF 2018), state control over many sectors of the economy which restricts competition, barriers to entrepreneurship and, despite high spending on education, poor educational attainment and huge inequalities in educational outcomes (OECD 2018). Moreover, Costa Rica is vulnerable to climate change, which is causing El Niño, flooding, landslides and earthquakes, among other phenomena, to be more severe, all of which has a knock-on effect on an already precarious infrastructure, on agricultural production and on manufacturing activities. Data from the National Disaster Committee (CNE) and MIDEPLAN show that, between 2005 and 2016, extreme weather events resulted in losses totalling USD 1.62 billion (NDC 2017). Furthermore, Costa Rica is affected by the deepening political crisis in neighbouring Nicaragua, which is disrupting trade between the two countries and resulting in increased migration towards Costa Rica.

The National Development Plan (Plan Nacional de Desarrollo, PND) sets out government policies for the four years of the President's mandate. The principal task of MIDEPLAN is to check the alignment between PND priorities and public investment projects. MIDEPLAN also approves the investment projects of public agencies (OECD 2015). Costa Rica's National Development Goals, published by MIDEPLAN in 2013 with the support of UNDP, complement the four-year National Development Plan. The plan for 2015-18 reflects the government's desire to bring about more effective, efficient, participatory, open 
and transparent governance in order to foster inclusive growth. This ambition is underscored by the fact that, in 2016, Costa Rica was the first country to sign a "national pact" to deliver on the SDGs. Although the country is facing an increasing fiscal deficit, it allocated a greater proportion of budgetary resources for 2016 to sectors connected with the SDGs (human development, social inclusion, infrastructure, the environment, energy, oceans and land use).

The SDGs were incorporated in the 2015-18 PND, the operative part of which outlined programmes and assigned resources for each of the SDGs, and designated their implementing bodies. The plan identified three priorities:

- Combating poverty;

- Achieving more sustainable output and consumption; and

- Building resilient infrastructure and sustainable communities. ${ }^{10}$

The National Climate Change Strategy (ENCC) to promote actions against climate change is to be implemented via citizen participation, innovation, research, technology changes and knowledge to support human security and competitiveness (NDC 2017). Costa Rica's overarching objective is to achieve 100\% renewable energy by 2030 (NDC 2017).

The 2018 Doing Business report indicates that Costa Rica stands at 61 in the ranking of 190 economies. In terms of access to credit, ${ }^{11}$ the Costa Rican economy scores 7.0 (out of 8 ) on the depth of credit information index and 10.0 (out of 12) on the strength of legal rights index (World Bank 2016). ${ }^{12}$ Costa Rica registers a low score in terms of protecting minority investors and stands at 165 in the ranking of 190 economies (World Bank 2018). The World Economic Forum (2018) rated government bureaucracy as "inefficient", and highlighted "inadequate supply of infrastructure", "tax rates" and "access to financing" as the most problematic factors for doing business in Costa Rica (World Economic Forum 2018). At the global level, Costa Rica ranked $52^{\text {nd }}$ in terms of ease of registering property (World Bank 2016). Corruption is a significant problem in Costa Rica, and the country stands at 59 in the ranking of 176 countries on the Corruption Perceptions Index 2017 (Transparency International 2018). ${ }^{13}$

\subsection{The development finance landscape}

Open trade and foreign direct investment (FDI) are the two factors that have led to Costa Rica's economic success, and they form an integral part of its growth model (OECD 2018). Strong FDI inflows (see Figure 1), favoured by an educated population and a friendly FDI regime, have supported Costa Rica's structural transformation from a rural and agriculture-based economy to one with a more diversified structure that is integrated into global value chains (OECD 2018). Although Costa Rica was severely hit by the global financial crisis in 2008-09, the recession was short lived as growth rebounded quickly to almost 5\% in 2010-12, on the back of strong FDI inflows, in high-tech manufacturing and knowledge-intensive services (OECD 2018). In Costa Rica, there is a tendency for export-

\footnotetext{
${ }^{10} \mathrm{See}$, for example, https://sustainabledevelopment.un.org/memberstates/costarica.

${ }^{11}$ The access to credit indicator examines "the depth of credit information systems and the effectiveness of collateral and bankruptcy laws in facilitating loans".

${ }^{12}$ The highest scores indicate more credit information and stronger legal rights for lenders and borrowers (World Bank 2016).

${ }^{13}$ The CPI uses a scale of 0 (highly corrupt) to 100 (very clean;).
} 
oriented firms to be dynamic and innovative due to inward FDI and well-developed links with global value chains, whereas domestic firms concentrate more on low value-added activities. For these low value-added products, domestic firms often employ unskilled workers operating in the informal economy, which accounts for about $40 \%$ of total employment. Although the country benefited from high levels of inward FDI, FDI spillovers to local firms have been relatively insignificant and the country's overall productivity growth remains limited (OECD 2016).

\subsubsection{Costa Rica as recipient and provider of $O D A$}

According to the OECD DAC Creditor Reporting System, in 2016, the country received gross ODA $^{14}$ of USD 127.4 million $^{15}$ from DAC and non-DAC countries and from multilateral organisations. The principal ODA providers were Japan (43\% of total ODA), Germany (31\%) and the European Union (21\%). Between 2012 and 2016, the country received an average of USD 91.5 million per annum. ${ }^{16}$ However, the data show a rising trend in real terms, from USD 57.2 million to USD 127.4 million between 2012 and 2016.

In terms of other official flows (OOF), ${ }^{17}$ Costa Rica received USD 182.2 million in 2012 and USD 371.8 million in 2016, the majority of which came from the International Bank for Reconstruction and Development (45\%) and the Inter-American Development Bank (42\%). Costa Rica also receives officially supported finance in the form of export credits, which amounted to USD 6.3 million in 2016 (see Table 2).

Table 2. Official development finance and officially supported export credits to Costa Rica

\begin{tabular}{lccccc}
\hline Type of flow (USD million) & 2012 & 2013 & 2014 & 2015 & 2016 \\
\hline ODA (concessional resources) & 57.2 & 66.6 & 78.5 & 144.5 & 127.4 \\
OOF (non-concessional resources) & 182.2 & 215.8 & 422 & 309 & 371.8 \\
Officially supported export credits & 5.9 & 2.2 & 50.5 & 124.2 & 6.3 \\
\hline
\end{tabular}

Note: Gross disbursements, 2016 prices, from all DAC, non-DAC providers and multilateral institutions. Source: OECD (n.d.[1]), Creditor Reporting System, https://stats.oecd.org/

Costa Rica also receives development finance from emerging providers. According to Aid DATA, total pledges of official development finance from People's Republic of China amounted to USD 892 million in 2014, including USD 395 million of ODA-like flows and USD 397 million of OOF-like flows and USD 100 million of vague official finance (Aid data 2018).

During interviews with the administration, it became apparent that Costa Rica would like to improve the transparency and accountability of resources received from bilateral and multilateral co-operation partners. Generally speaking, development partners do not follow national reporting formats and do not break down the financial information provided to the country (especially in relation to technical co-operation). There used to be a roundtable led by Costa Rica with its development partners to co-ordinate activities, but this roundtable is

\footnotetext{
${ }^{14}$ In this report, the term ODA refers to bilateral ODA and concessional outflows from multilateral organisations.

${ }^{15}$ In disbursements, 2016 prices from all DAC, non-DAC and multilaterals reporting to the Creditor Reporting System of the OECD available at: https://stats.oecd.org/index.aspx?DataSetCode=CRS1.

${ }^{16}$ OECD-DAC Creditor Reporting System database.

${ }^{17} \mathrm{OOF}$ includes both bilateral OOF and non-concessional outflows from multilateral organisations.
} 
no longer operative. The opacity as to how external resources allocated to Costa Rica are used causes, in turn, difficulties for national accounting.

Costa Rica is both a provider and recipient of development co-operation. In 2015, Costa Rica channelled USD 10 million through multilateral organisations. ${ }^{18}$ In 2014 , Costa Rica's total concessional development finance amounted to USD 24 million. ${ }^{19}$ These 24 million include contributions to multilateral organisations (which Costa Rica does not assimilate to official development assistance) and other support. Costa Rica provides inkind technical co-operation to countries at an equal or similar level of development using finance from bilateral and multilateral sources and through South-South and triangular co-operation mechanisms. Finally, Costa Rica also provides assistance to refugees and migrants (mostly from Nicaragua and the Bolivarian Republic of Venezuela ["Venezuela"]) although an estimate of the costs was not provided by the country. An estimate of outward flows from Costa Rica as a provider, as per available data, can be found in Annex D.

\subsubsection{Non-official flows to Costa Rica}

The results of the 2015 DAC survey on mobilisation showed that, between 2012 and 2015, finance mobilised from the private sector received by Costa Rica amounted to USD 708.5 million, or an average of USD 177 million per year. ${ }^{20}$

Costa Rica currently has free trade agreements (FTA) with China, Singapore and the Republic of Korea (EIU 2018). In addition, the country implemented the Dominican Republic-Central America Free Trade Agreement (CAFTA-DR) in 2009. Costa Rica is also a member of the FTA between the Central American Integration System (of which it is a member) and the EU, which is in force since October 2013 (EIU 2018). As in previous years, Costa Rica will continue to benefit from the EU's sub-regional Central America Programme (EUR 120 million) during the period 2014-2020 (European Commission 2018).

According to UNCTAD statistics, FDI flows in Costa Rica amounted to USD 2.5 billion in 2016 and USD 3.0 billion in 2017. In terms of geographical origin of FDI flows, in 2012, ${ }^{21}$ the largest investors in Costa Rica were from the United States (USD 1.051 billion), Mexico (USD 346 million) and Spain (USD 318 million). In terms of FDI stocks, the most represented countries were the United States (USD 11.513 billion), Spain (USD 1.359 billion) and the United Kingdom (USD 902 million). ${ }^{22}$

\footnotetext{
18 The difference between the estimates for 2014 and 2015 is due to an adjustment in OECD estimates of Costa Rican contributions to multilateral organisations. The estimates for 2015 are based on additional information received from the Costa Rican Treasury.

${ }^{19}$ OECD estimates based on the Government of Costa Rica, 2014 and 2015, and websites of multilateral organisations.

${ }^{20}$ USD 76.5 million in the form of guarantees, USD 4.7 million in the form of credit lines, USD 619 million in the form of shares in CIVs (see Benn et al. 2016).

${ }^{21}$ The most recent figures for FDI flows disbursed by country of origin according to UNCTAD statistics relate to 2012.

${ }^{22} \mathrm{See}$, for example, https://unctad.org/en/Pages/DIAE/FDI\%20Statistics/FDI-Statistics-Bilateral.aspx.
} 
Figure 1. Net FDI inflows

Average 2010-2016

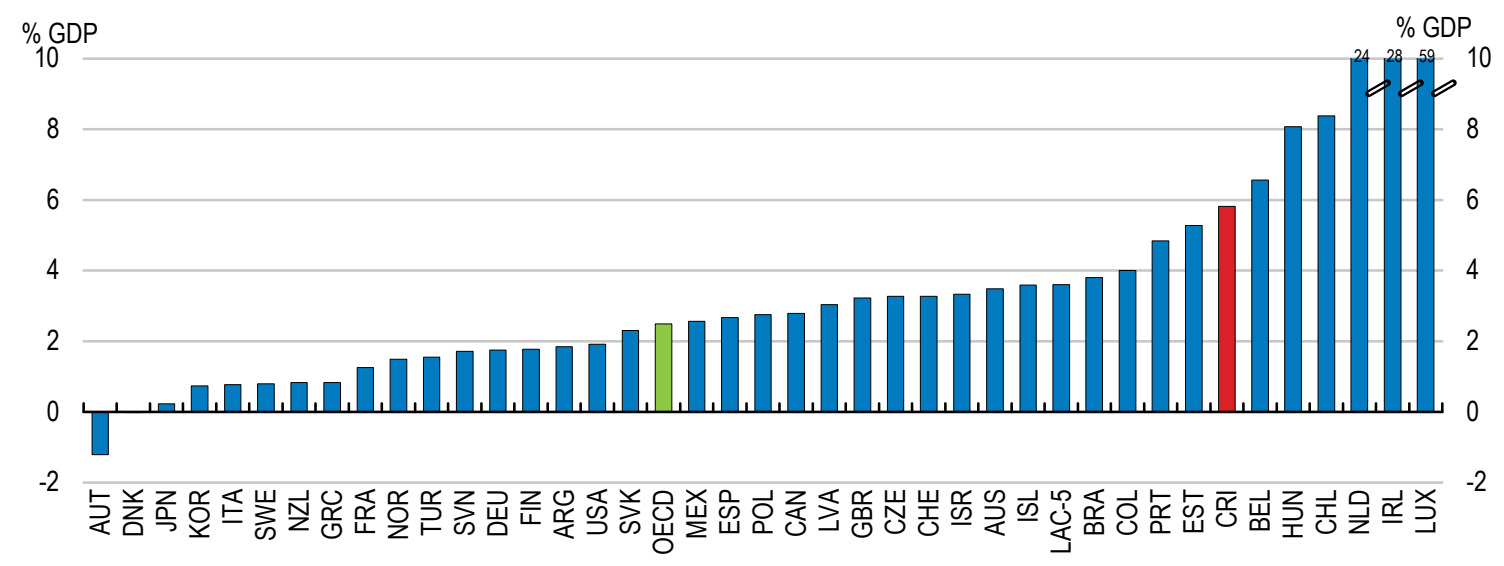

Source: OECD (2016), Survey on Costa Rica (2016), Paris, OECD, https://doi.org/10.1787/eco surveys-cri2016-en.

According to the "Investment Climate Report Statements for 2018" by the US Department of State, Costa Rica's high-tech and tourism sectors are the main clusters of FDI inflow. Costa Rica attracts manufacturers of relatively high technology as well as manufacturers of medical appliances and service companies seeking skilled labour.

Costa Rica is also a recipient of remittances. According to World Bank data, Costa Rica received the equivalent of USD 442 million in personal transfers in 2017 (World Bank 2017).

Finally, illicit financial flows constitute a major concern for Costa Rica. According to the Global Financial Integrity report, total illicit outflows and total illicit inflows represented respectively between $34 \%$ and $52 \%$ of Costa Rica's exports and $4 \%-5 \%$ of imports in the period 2005-14 (Global Financial Integrity 2017). 


\section{Part IIII. Costa Rica's perspective on the emerging Reporting Instructions}

This part of the report presents the interviews with Costa Rican stakeholders about the TOSSD Reporting Instructions. The text broadly follows the structure of these instructions as available at the time of the pilot study, even though some sections were grouped to avoid repetition. Comments by Costa Rican stakeholders have been inserted after relevant paragraphs for readers to understand the context in which these comments were made. For the purposes of this pilot study, the version of the Reporting Instructions used was version 1.0 of 12 of July 2018. 


\section{Preamble to the Reporting Instructions, main concepts and definitions}

\subsection{Definition of TOSSD}

The total official support for sustainable development (TOSSD) statistical measure includes all officially supported resource flows to promote sustainable development in developing countries and to support development enablers and/or address global challenges at regional or global levels.

Only one comment was received on the preamble: namely, that reporters on TOSSD should abide by the principles of accountability and measure the impact of their activities.

All the stakeholders interviewed felt that the definition of TOSSD was clear.

Some stakeholders suggested that the language of the instructions in Spanish could be simplified. For example, it was proposed that "estadistica TOSSD" ("TOSSD statistics") could be used, rather than "métrica estadistica TOSSD" ("TOSSD statistical measure"). Likewise, it was proposed to use "cooperación total al desarrollo sostenible" ("total co-operation on sustainable development") rather than "apoyo oficial total al desarrollo sostenible" ("total official support for sustainable development"), which has North-South connotations that do not encompass the horizontal and multi-directional nature of SouthSouth and triangular co-operation. Moreover, it was thought that the concept of "habilitadores del desarrollo" ("development enablers") was too abstract, and it would be useful to employ nomenclature stressing the "global impact" angle.

Furthermore, some aspects of the definition were clarified:

- Debt repayment implies a reduction in net TOSSD flows to the debtor country. The initial payment, if it came within the TOSSD framework, may have contributed to sustainable development in the receiving country, and repayments will be deducted from the debtor's TOSSD flows.

Some suggestions were also made:

- The framework should include national contributions supplementing external contributions (counterpart funding), as well as flows of technical co-operation (which are sometimes higher than the external flows provided to Costa Rica).

- TOSSD should include private flows mobilised by public finance, including in-kind technical support provided under schemes involving the private sector.

- The text of the definition should specify that resource flows include both inward and outward flows.

\subsubsection{Sustainable development}

The concept of "Sustainable Development" is defined as development that meets the needs of the present without compromising the ability of future generations to meet their own needs. ${ }^{23}$. "Sustainable

\footnotetext{
${ }^{23}$ Definition first used in the Brundtland Report. (See Report of the World Commission on Environment and Development: Our Common Future", Chapter 2 "Towards Sustainable Development", p. 41, New York: UN, 1987.) It contains within it two key concepts: (i) the concept of "needs", in particular the essential needs of the world's poor, to
} 
Development" in the TOSSD context is inherently linked to the Sustainable Development Goals as agreed in the 2030 Agenda. ${ }^{24,25}$ Activities recorded as TOSSD support the implementation of the SDGs by generating sustainable economic growth, ensuring social inclusion, without compromising the environment. As and when the 2030 Agenda is concluded and replaced by another framework, the TOSSD measure will be updated to link to that framework.

Costa Rica supported the proposed definition of sustainable development for TOSSD, regarding it as broad enough and sufficiently consensual at the international level. However, in the interviews with local stakeholders, it became clear that this definition was also too imprecise and could be of little operational value in the context of Costa Rica, where sustainable development has served as a cornerstone of its development strategy for several decades. Sustainable development is, moreover, a framework that pervades all the activities of public institutions in Costa Rica, albeit understandably there are inherent conflicts between institutions about how and when one aspect of sustainable development should be prioritised over another, for instance when it comes to food security. These activities include international and trade agreements to which Costa Rica has adhered, and the private sector, both national and international, that has to comply with relatively strict legislation on social and environmental matters. Costa Rica is, indeed, seeking to attract this kind of foreign investment.

The following points emerged:

- The definition could refer to the "polluter pays" principle, and hence the duty of countries that have caused greater pollution to pay more in order to guarantee a global framework for sustainable development for all.

- Costa Rica felt that unsustainable investments should not be included in TOSSD. In cases of "brown" investments, Costa Rica has tended not to approve them, as any project, whether external or internal, has to be in line with the National Development Plan (Plan Nacional para el Desarrollo, PND), in which sustainability is a central feature. The new PND for 2019-22 was presented alongside the National Public Investment Plan (Plan de Inversiones Públicas, PNDIP) and will take guidance from the SDGs, thus strengthening the sustainability dimension in Costa Rica.

- It was also mentioned that a methodology should be developed to separate out the "brown" part of ODA and include only the "green" ODA in TOSSD.

- TOSSD should be reported at SDG target level. Otherwise, if it is linked to the goals, TOSSD could lack precision. The overlapping nature of targets and goals also needs to be acknowledged, so that TOSSD data are not analysed in silos by sector of activity. In particular, the difficulty of capturing cases where an investment in favour of one SDG could be detrimental to another SDG was mentioned. An example of an activity that could support one goal but have negative

\footnotetext{
which overriding priority should be given; and (ii) the idea of limitations imposed by the state of technology and social organisation on the environment's ability to meet present and future needs.

${ }^{24}$ See "Transforming our world: the 2030 Agenda for Sustainable Development": https://sustainabledevelopment.un.org/post2015/transformingourworld.

${ }^{25}$ Taking into account linkages with sustainable development frameworks established at regional level, e.g. by the African Union Commission. See https://au.int/en/agenda2063.
} 
repercussions on another is the construction of a geothermal power station on a protected area around a volcano.

- TOSSD should be linked to the 2030 Agenda and be updated as and when this is replaced by another post-2030 framework.

- According to Costa Rica, income per capita cannot be the only indicator of development, nor the only measure of funding needs of a given country.

- At regional level, Costa Rica participates in the Central American Integration System (Sistema de Integración Centro Americana, SICA), where it stands out in terms of its environmental regulation performance. It would be important for TOSSD to be linked to the 2030 Agenda, which is universal and should, therefore, apply to all countries of the region. Moreover, TOSSD criteria should be laid down at regional level to encourage a "race to the top" in the region and, if possible, at sub-regional level: there was little point in comparing Costa Rica exclusively with Latin America and the Caribbean as a whole, and greater sense in categorisation at Central American level.

- The establishment of sustainability criteria to make this definition operational (such as biodiversity, emission standards, environmental footprint, etc.) should be a task to be tackled by the regions or even the sub-regions. This would mean basing TOSSD on the specific characteristics of each region. The Economic Commission for Latin America and the Caribbean (ECLAC) could facilitate this process at the level of Latin America and the Caribbean, for example, drawing on exercises already carried out, such as the Biodiversity Finance Initiative (see Box 1).

\section{Box 1. The Biodiversity Finance Initiative (BIOFIN)}

BIOFIN is a USD 15 million programme implemented by the United Nations Development Programme (UNDP), with the financial support of the European Union (EU), Germany and Switzerland. BIOFIN is working with partner countries, including Costa Rica, to help them with national resource mobilisation through the development of biodiversity and ecosystem services strategies. UNDP has developed a methodology, called the "BIOFIN Workbook", which includes a thorough review of the current policy, institutional and fiscal frameworks affecting biodiversity and ecosystem services and of the impact, effectiveness, alignment and coherence of public policies and institutions. BIOFIN helps countries to identify the financing gaps in relation to biodiversity and ecosystem services, and to assess what mechanisms and policies could be used to fill these gaps at national level. The programme aims at helping countries to fund their National Biodiversity Strategy and Action Plans (NBSAPs), thereby implementing the Strategic Plan for Biodiversity 2011-20 and the 20 Aichi Targets at the national level. BIOFIN is currently being piloted in 19 countries across Asia, Africa and Latin America. 
Source: UNDP (United Nations Development Programme) (2014), The Biodiversity Finance Initiative - An overview and key progress summary, information document, UNEP/CBD/WGRI/5/INF/13, 10 June 2014, and UNDP (2013b), "Transforming Biodiversity Finance: The Biodiversity Finance (BIOFIN) Workbook for assessing and mobilizing financial resources to achieve the Aichi Targets and to implement National Biodiversity Strategies and Action Plans", Version 3.0 Draft for Distribution, June 4, 2013.

\subsubsection{Resource flows}

The term "resources" in the TOSSD definition covers both financial and technical resources. ${ }^{26}$

Costa Rica felt that the definition of resource flows is clear. Costa Rica, as a country with a "dual" role, attaches great importance to the inclusion of technical co-operation in a broad sense, encompassing activities such as exchanges of experience, technology and other resources, knowledge management and education, training and awareness-raising activities.

\subsubsection{Officially supported}

In the context of TOSSD, "officially supported resources" are defined as:

a) resources provided by:

i) official agencies, including state and local governments, or by their executive agencies,

ii) state-owned companies and enterprises under government control, ${ }^{27}$ and

iii) other enterprises under significant government influence. ${ }^{28}$

b) private resources mobilised by official interventions, where a direct causal link between the official intervention and the private resources can be demonstrated.

Costa Rica regarded this definition as sufficiently broad and appropriate to cover all initiatives. There is no institution in Costa Rica that collects data on private finance mobilised with public funds, although it would be useful to have this information in the future. Some information might be collected by various institutions (such as the Central Bank, the MIDEPLAN), but the information would be fragmented. Costa Rica does not have any enterprises under significant government influence (only public- or private-sector companies).

The clearest example of an initiative where resources could have been leveraged is an environmental trust fund that emerged from a US-debt swap. The country wonders whether

\footnotetext{
${ }^{26}$ The AAAA considers that international co-operation to support the implementation of the 2030 Agenda comprises both financial and technical resources. See http://www.un.org/esa/ffd/wpcontent/uploads/2015/08/AAAA Outcome.pdf.

${ }^{27}$ Corporations over which the government secures control by owning more than half of the voting equity securities or otherwise controlling more than half of the equity holders' voting power, or through special legislation empowering the government to determine corporate policy or to appoint directors.

${ }^{28}$ This category is included to recognise that governments can exercise influence in many different ways beyond the mere control of a company via voting powers. (See, for example, Chapter 6, Section B in the IMF's Balance of Payments and International Investment Position Manual - Sixth Edition, BPM6.) TOSSD aims to capture the entirety of official interventions, but, given the variety of reporting countries, it is ultimately left at the discretion of the reporter to determine whether companies under significant government influence should be included.
} 
these resources could potentially be regarded as private flows mobilised by the United States.

\subsection{A two-pillar approach}

TOSSD is a two-pillar framework that tracks officially supported i) cross-border resource flows to developing countries and ii) finance for development enablers and global challenges at regional and global levels [the Global Public Goods agenda], as illustrated in Figure 2.

Figure 2. The two-pillar TOSSD statistical measurement framework

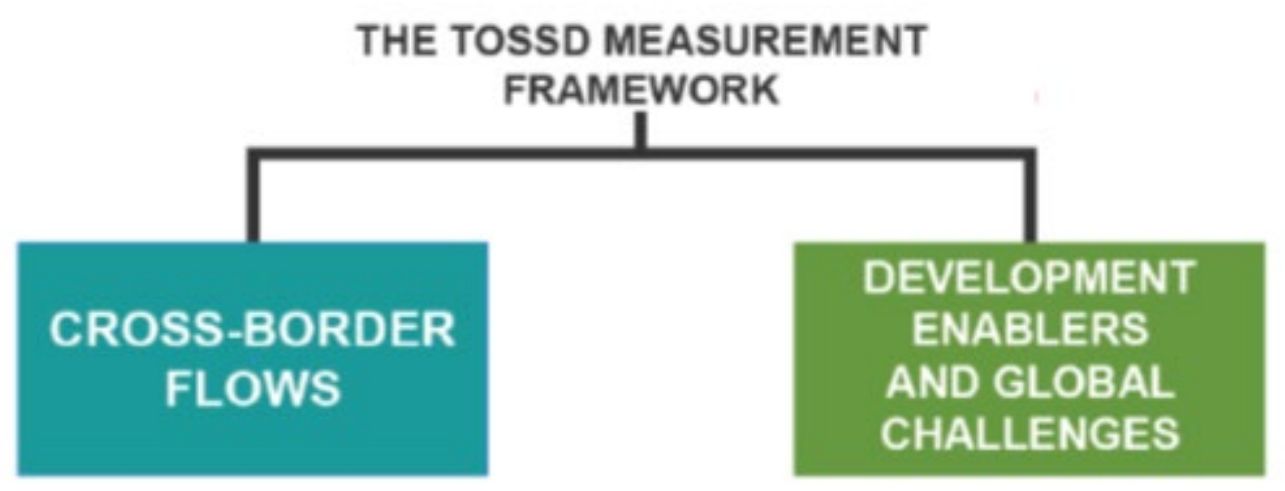

For most of the stakeholders interviewed, the distinction between the two pillars was not always clear, and for some of them it seemed complicated:

- Once it was explained that the flows to be recorded under Pillar I were based on the principles of the balance of payments of "residents" and "non-residents", the area covered by Pillar I was better understood than that of Pillar II. There was some linguistic confusion (in Spanish) about the concept of "flujos transfronterizos" ("cross-border flows"), as these designated operations between countries with shared terrestrial borders (such as Costa Rica and Nicaragua or Costa Rica and Panama). It was recommended that the title of this pillar should be changed to "flujos externos para el desarrollo" ("external development flows"). Stakeholders also suggested that debt relief, scholarships and South-South co-operation could be included in Pillar I.

- Pillar II was more difficult to define and conceptualise:

- The concept of development enablers is unclear, and what some stakeholders saw as an enabler, others regarded as a cross-border flow (such as a road between countries or a park improving local and global biodiversity). For some stakeholders, it was too vague, and could include all contributions that help to achieve the SDGs. Moreover, in some cases, it was argued that Pillar II could turn into a kind of a "catch-all" category, with everything that does not fit into Pillar I ending up in Pillar II by default.

- Some activities have a markedly global character, such as peacekeeping, support for refugees or migrants or combating climate change. Support to refugees and migrants was seen rather as a global public good (as migration 
generated benefits for the receiving countries), whereas climate change is clearly seen as a challenge.

- Other stakeholders pointed to the need for a regional pillar, which could include cross-border trade facilities, investments in regional (Central American) electrification systems and roads, activities to protect the oceans or a crossborder natural park, since, in these cases, there would be no transfer of resources between countries in the region, although development would be fostered. Accordingly, there would be a preference for developing a pillar or sub-pillar identifying development enablers and regional challenges. Costa Rica could be regarded as belonging to the Latin America and Caribbean region, but it would be useful to treat the country as part of Central America as well.

- Likewise, it was requested that the expression "países en desarrollo" ("developing countries"), which implied the idea of North-South co-operation, should be narrowed down. The use of "países incluidos en la lista de receptores de TOSSD" ("countries on the list of TOSSD-recipient countries") was preferred.

- Lastly, there were calls for developing criteria to classify activities under the two pillars (and, if applicable, a regional pillar).

\subsection{Reporting principles}

\subsubsection{Statistical quality standards in the TOSSD system}

The TOSSD statistical framework is subject to the United Nations Statistics Quality Assurance Framework. ${ }^{29}$ The governance of the TOSSD measure will ensure the quality of the institutional environment (objectivity, impartiality, transparency and credibility), essential to build trust, which is the very foundation of a statistical system.

Costa Rica considered that the governance of TOSSD should be linked to the UN. In order to secure the greatest political support, it was suggested that the governance of TOSSD should be placed under the ECOSOC. For the technical aspects (e.g. data collection), the OECD and other regional organisations, such as ECLAC for Latin America and the Caribbean, appeared as the most appropriate organisations.

\subsubsection{Activity-level reporting}

All TOSSD resource flows are reportable at the activity level. In certain cases, some aggregation is permitted to limit the reporting burden and number of records.

Most of the stakeholders interviewed - even those working on development co-operation with Development Assistance Committee (DAC) members - were unaware of the OECD (CRS) database ${ }^{30}$. It is therefore expected that, once the TOSSD database is created, a special effort will be needed to make relevant stakeholders in Costa Rica aware of its existence.

\footnotetext{
${ }^{29}$ Ibid.

${ }^{30}$ Available at https://stats.oecd.org/Index.aspx?DataSetCode=crs1.
} 


\subsubsection{Point of measurement}

TOSSD resource flow data are reportable on a calendar year basis. Both commitment and disbursement data are collected. A commitment is a firm written obligation by the provider, backed by the appropriation or availability of the necessary funds, to provide specified resources under specified financial terms and conditions and for specified purposes for the benefit of the recipient. Commitments are considered to be made at the date the financial agreement is signed or the obligation is otherwise made known to the recipient. A disbursement is the placement of resources at the disposal of the recipient.

The definitions of "commitment" and "disbursement" were clear to stakeholders interviewed in Costa Rica.

\subsubsection{Currency}

TOSSD data are reported in the currency in which the transaction takes place. However, for consolidated data presentations and dissemination, the reference currency is the United States dollar (USD). Data reported in currencies other than USD will be converted to USD using annual average exchange rates. ${ }^{31}$

There was some concern about how the exchange rate between a national currency and the United States dollar (USD) was going to be applied. It was explained that the Secretariat would use the annual average exchange rate to mitigate day-to-day fluctuations in the course of the exercise.

\subsection{Main statistical concepts}

\subsubsection{Provider and recipient}

TOSSD data are collected mainly from provider countries and institutions. These data are complemented by data from recipient countries, reported on a voluntary basis, when possible and in line with their capacities. ${ }^{32}$

In Costa Rica's view, it is the provider countries that should report on TOSSD. Costa Rica has a dual role as provider and recipient. It therefore finds useful to have information from both perspectives. Although the information from the recipient could be used to triangulate data from providers, it was felt that this would be a rather complex operation. It would require setting up a data reconciliation process between data on TOSSD to Costa Rica and data recorded by Costa Rica in its country systems.

Costa Rica would be able to report data for all fields in the TOSSD reporting form, apart from those on private finance mobilised, which are not currently collected. As a provider of South-South co-operation, Costa Rica suggested that the categories of "strict SouthSouth co-operation" (where there is a non-reimbursable financial flow between the provider and the recipient) and "bi-directional South-South co-operation" (where there is

\footnotetext{
${ }^{31}$ See IMF International Financial Statistics at http://data.imf.org/?sk=4C514D48-B6BA-49ED-8AB9-52B0C1A0179B.

${ }^{32}$ Provider countries and institutions should provide technical capacity building for developing countries willing to set up their own systems to report and analyse TOSSD data.
} 
an exchange of non-reimbursable financial flows and knowledge) be included in the reporting form.

Bilateral providers are countries and territories that have a development co-operation policy and undertake activities in support of sustainable development in third countries.

Multilateral providers are international agencies, institutions, organisations or funds whose members are governments and who are represented at the highest decision-taking level in the institution by persons acting in an official capacity and not as individuals.

TOSSD recipients are defined in the list of eligible recipient countries and territories, but also include international institutions.

Costa Rica stressed that the category of "dual-status co-operation partner" should be included within the definition, to differentiate it from the concept of "cooperante neto" (provider only). Costa Rica is a dual partner, a recipient of co-operation and a provider of technical co-operation. Although it also gives contributions to multilateral organisations, these contributions are in the form of mandatory membership fees. Some Ministerial Departments, including MIDEPLAN and the Ministry of Foreign Affairs, did not think that these contributions could be regarded as development co-operation, whereas other departments did. Moreover, Costa Rica supports refugees and migrants in its territory, provides humanitarian assistance, contributes to peacekeeping operations and its academic system is involved in research on regional and global subjects. It also has fixed costs in the administration of its co-operation activities.

\subsubsection{Channel of delivery}

The channel of delivery is the entity that has implementing responsibility over the activity and is normally linked to the provider agency by a contract or other binding agreement, and is directly accountable to it. It is a key element of the TOSSD framework since it helps to identify the institution responsible for the execution of the activity, which is essential in order to track flows and improve accountability in both provider and partner countries.

Clarification of the definition was requested, because the entity responsible for the use of funds was not always the one that implemented the activity: either this should be clarified, or two categories could be created to cover both aspects (administrator of funds and entity responsible for implementing initiatives - projects, programmes and activities).

\subsubsection{Financial instruments}

TOSSD resource flows are provided through numerous financial instruments. These are categorised as grants, debt instruments, mezzanine finance instruments, and equities and shares in collective investment vehicles. Included are also instruments that generate contingent liabilities but not necessarily a flow from the provider to the recipient (e.g. guarantees).

There were no comments about the definition of financial instruments. 


\section{TOSSD pillar 1: cross-border resource flows in support of sustainable development}

\subsection{Scope of cross-border resource flows pillar}

\subsubsection{Categories of resource flows covered}

The cross-border resource flows pillar covers resources extended to TOSSD-eligible recipient countries in support of sustainable development by bilateral and multilateral providers (Figure 3). The major breakdown is between grants and in-kind contributions on the one hand, and financial transactions on the other hand. No distinction is made between concessional and non-concessional transactions. Resources mobilised from the private sector by official interventions are also included. However, they are presented under a separate heading as the funds do not necessarily originate from the provider country and may even be domestic i.e. originate from the recipient country.

Costa Rica does not accept development co-operation projects unless they are sustainable. Costa Rica would therefore be relatively well prepared for TOSSD. The following items should not be included in TOSSD:

- Administrative costs of development co-operation offices based in Costa Rica;

- Contributions made primarily for religious purposes, e.g. rebuilding of churches;

- Counter-terrorism activities; and

- Economic and environmental activities that are not aligned with sustainable development (as set out in the National Development and Public Investment Plan), but which are still important for the country's development (for example, there was a proposal for an oil refinery project in Costa Rica, which, in the end, did not go ahead. This kind of initiatives should not be included in TOSSD).

On the other hand, TOSSD should include the following items:

- Development-oriented social and cultural programmes (e.g. support for artistic or sports events, musical concerts, etc.);

- Research activities, whether in the provider country or elsewhere;

- Scholarships/imputed student costs;

- Peace- and security-related activities (such as peacekeeping operations);

- Refugees and migrants, in particular in-donor refugee and migrant costs (Costa Rica does not keep separate accounts for care of refugees and migrants); and

- Debt relief. 
Figure 3. Overview of TOSSD cross-border resource flows pillar

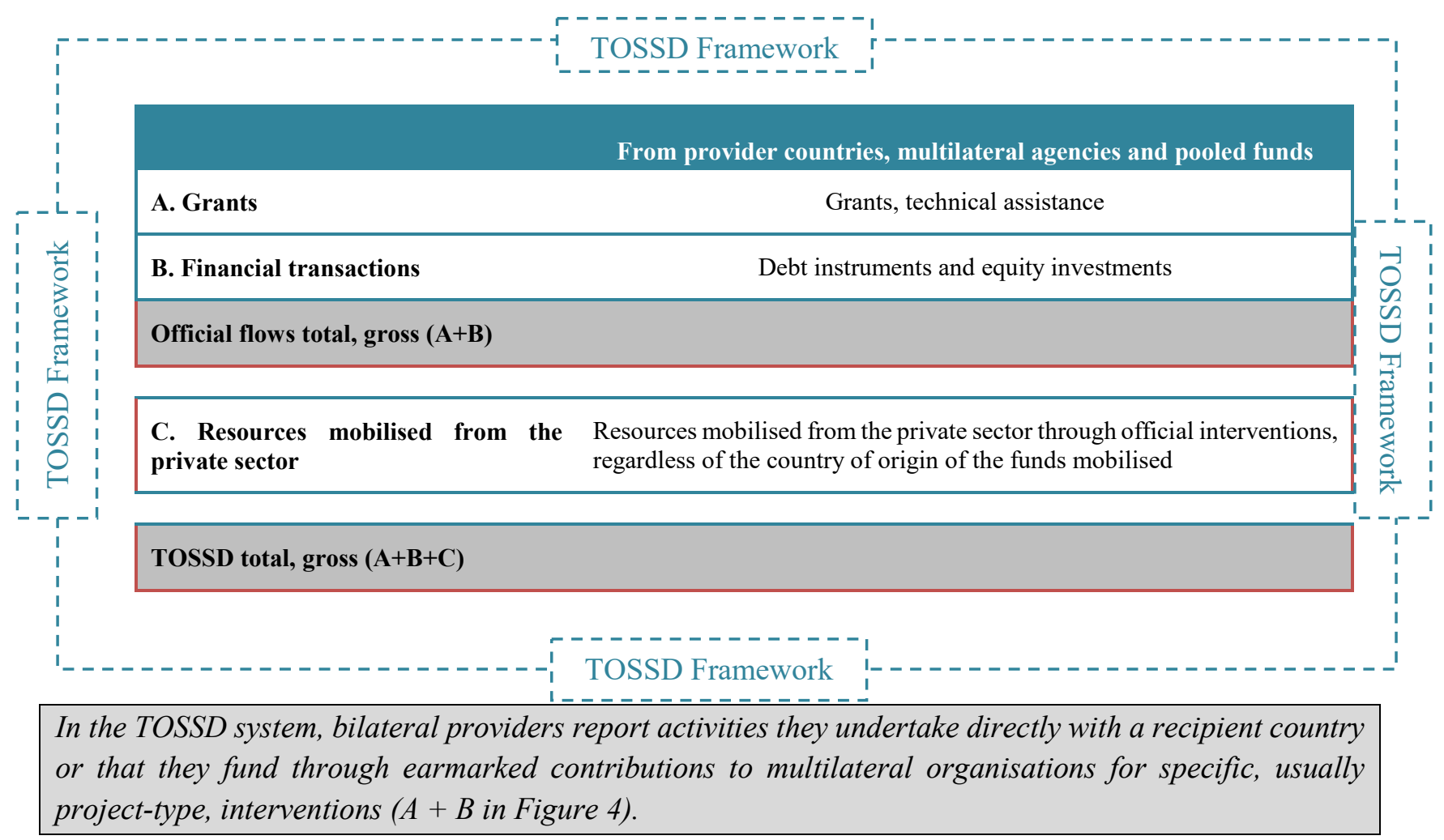

Figure 4. Reporting on TOSSD by provider

Provider countries report on A and B. Multilateral providers report on C and D.

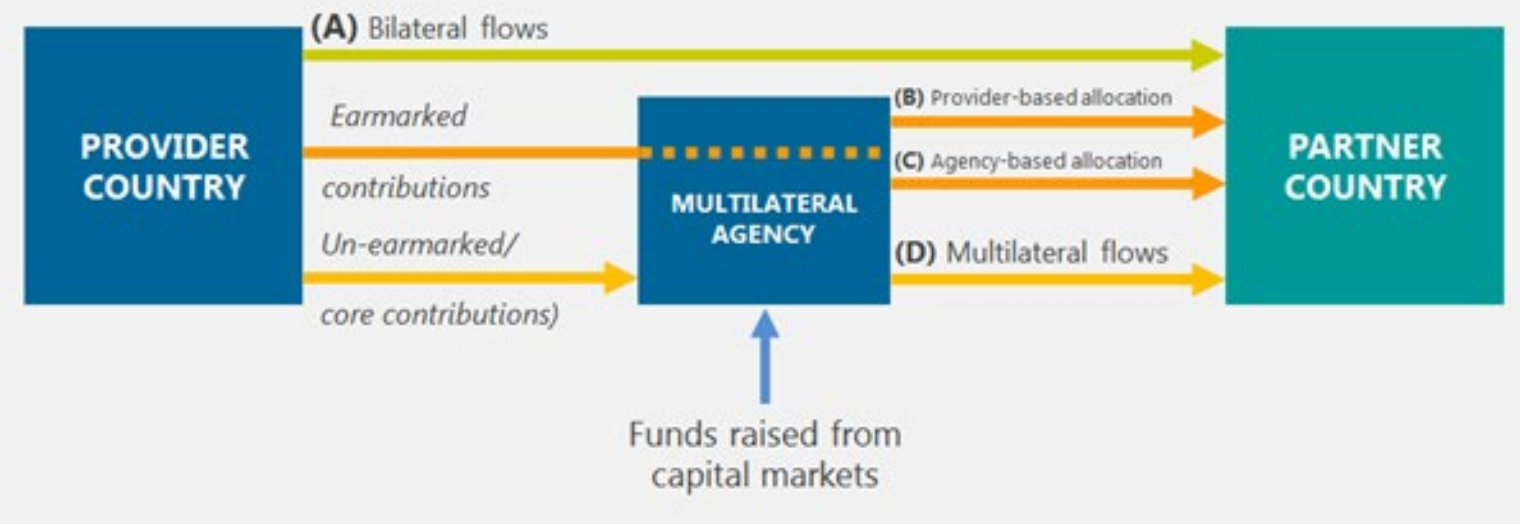

In the TOSSD system, multilateral providers report on activities that they undertake under their own responsibility (decisions on resource allocations to specific purposes are made by the institutions themselves) ( $C+D$ in Figure 4). In the case of trust funds managed by several multilateral organisations, it should be considered, on a case-by-case basis, which institution is better placed to report on TOSSD outflows, usually the lead institution. 
Costa Rica does not have a strategy for co-ordinating its work with multilateral organisations. This work depends on each subject matter, and each institution uses its own discretion in deciding allocations. To date, most of the budgets have consisted of contributions and funding required in order for Costa Rica to be a member of an institution. Decisions on funding (hence being a member of) a multilateral institution have to be approved by an inter-institutional group consisting of the Ministry of Foreign Affairs and Worship, the Ministry of Finance and the Central Bank, as well as the Congress of Deputies.

Even so, Costa Rica considered that contributions earmarked for a specific purpose and un-earmarked/core contributions to multilateral organisations should not be included in TOSSD.

There were no comments about the management of trust funds. It was thought that the UN would have the necessary information to report on its trust funds.

\subsubsection{Maturity of transactions covered}

For capital flows, the scope of the TOSSD cross-border resource flows pillar is generally limited to longterm operations (i.e. with a maturity exceeding one year), in line with balance of payments statistics and/or systems of national accounts. Data will also be collected on short-term financial transactions by multilateral development banks to support sustainable development in TOSSD recipient countries. In TOSSD data presentations, short-term and long-term finance will be presented separately.

Most of the capital flows that reach Costa Rica from the private sector are regarded as foreign direct investment (FDI). FDI towards Costa Rica is in line with the country's sustainable development model, giving priority to environmental and social criteria, although it also helps stabilise the country's exchange system, since Costa Rica does not export natural resources.

Costa Rica (through the Central Bank) receives official short-term finance, although this finance consists primarily of credit line facilities to support private sector operational activity (mainly of parent companies). This finance would serve to support treasury management, and hence jobs and the country's economic activity, and would therefore support the sustainable development of companies and the country. It is therefore felt that it should count as TOSSD. Most of the financing, however, is longer-term.

\subsection{Specific eligibility criteria}

\subsubsection{Eligibility criteria regarding sustainable development}

In TOSSD, an activity is deemed to support sustainable development if it directly contributes to at least one of the SDG targets as identified in the official list ${ }^{33}$ of SDG targets developed and maintained by the United Nations Statistical Commission (UNSC).

\footnotetext{
${ }^{33}$ https://unstats.un.org/sdgs/indicators/indicators-list.
} 
There may be cases where reporters cannot find a direct link with one of the SDG targets. In these cases, the reporter will still be able to report the activity, linking it to a goal and providing an appropriate justification in the relevant field of the TOSSD activity-level reporting form.

Mapping at goal level is too vague. The eligibility criteria should be set at target level rather than goal level.

Activities promoted by co-operation partners that are not in line with the National Development and Public Investment Plan can be approved only on the basis of political criteria and are exceptional. Most of the co-operation partners operating in Costa Rica present only projects that are aligned with the Plan, and hence are sustainable. Some co-operation partners, indeed, are primarily focused on supporting Costa Rica in aligning the Plan and its implementation with the SDGs. However, it was recommended that these efforts should be increased, ensuring that all governmental stakeholders have guidance to support them in the process of institutional alignment with the 2030 Agenda. If there were to be a conflict between SDG targets, it was recommended that national legislation should prevail, and otherwise the 2030 Agenda should be used as a framework to determine whether or not an activity should be implemented, and whether or not it could count as TOSSD.

\subsubsection{TOSSD-eligible countries}

To count as TOSSD, an activity should involve a cross-border resource flow to a country on the List of TOSSD recipient countries. For any reporting year, this List includes:

i. All countries and territories that are present on the "DAC List of ODA recipients". ${ }^{34}$

ii. Other countries and territories that have activated the TOSSD opt-in procedure.

Any country or territory can activate the opt-in procedure at any point in time. The procedure is voluntary but needs to be motivated through the specific economic, social or environmental context that the country faces. Traditional donors are expected to not use the TOSSD opt-in procedure.

For Costa Rica, there would be no sensitivities about applying the opt-in procedure if the country was no longer on the DAC list of ODA recipients. Graduation from ODA status is a sensitive subject in Costa Rica, although there is little awareness about the process and criteria governing graduation, or of the (non-existent) links between graduation and the OECD accession process that is currently under way in Costa Rica. The criteria used by the Development Assistance Committee to decide on graduation from ODA status are based on income level (set by the World Bank). All least developed countries (LDCs) according to the United Nations are also included in the list of ODA recipients.

\subsection{Specific methods}

\subsubsection{Measurement of technical co-operation}

The implementation of technical co-operation activities may involve hiring experts or consultants in the international markets or deploying public officials of provider countries. In the first case, TOSSD records

\footnotetext{
${ }^{34}$ See http://www.oecd.org/dac/stats/daclist.htm.
} 
the costs incurred by the provider because those costs are already internationally comparable in monetary terms; in the second case, a specific methodology is used to estimate the costs in an internationally comparable manner.

Costa Rica has a database, SIGECI (International Co-operation Project Management System), which includes most of its technical co-operation (or non-reimbursable financial co-operation) activities, i.e. South-South co-operation activities (both strict and bidirectional), bilateral and triangular co-operation. Costa Rica has devised a methodology to quantify its technical co-operation (see below).

\section{Experts contracted in the international market}

If experts are hired in the international market, the price of the contract will be recorded in TOSSD, regardless of the country of residence of the expert. For locally-hired experts, ${ }^{35}$ technical co-operation is measured applying a specific methodology by which the costs can be estimated in an internationally comparable manner.

The development co-operation providers interviewed make use of national/local and international experts. They pay different salaries to these experts, with those for national or local experts sometimes being the same as, or higher than the salaries of international experts. This is because of the high level of experience offered by Costa Rican experts. As time goes on, co-operation partners tend to increasingly hire national or local experts.

Costa Rica, for its part, has developed a methodology to record in-kind technical co-operation (see Annex B). This methodology was drawn up by MIDEPLAN and should also be used by the various governmental institutions focal points implementing technical co-operation projects. This information should be collected by SIGECI from 2019.

The methodology measures both technical co-operation offered by Costa Rica (South-South and triangular co-operation) and the technical contribution made by Costa Rica to implement bilateral co-operation projects (for example, if officials have to travel to a third country for a conference). Technical co-operation is measured in financial terms and includes the following quantitative items:

- Direct costs: when Costa Rica is the country offering technical co-operation, the administrative and financial department provides a breakdown of direct costs. There is a standard table of costs for accommodation and per-diem according by recipient country, provided by the Office of the Controller General of the Republic. ${ }^{36}$ These costs also include domestic travel costs.

- Indirect costs: these are the administrative costs for arranging a trip, such as costs for delivering a travel authorisation and the issuance of a service passport, the use of Ministry equipment and office space, etc. It is a pre-set percentage estimated at

\footnotetext{
${ }^{35}$ Experts hired in TOSSD recipient countries receive a remuneration that is equivalent to national salary levels. An indication of local hiring could be remuneration in national currency or using the procedures of the partner country.

${ }^{36}$ The Office of the Controller General of the Republic is the supreme fiscal control authority of the State. As such, its mission is to ensure that public resources and goods are properly used and to contribute to the modernisation of the State through continuous improvement measures in the various public bodies.
} 
$5 \%$ of total costs for South-South and triangular co-operation projects (which tend to be of shorter duration) and 7\% for traditional bilateral co-operation projects.

- Daily cost of expert official: the basis for this is the average salary of a Grade 3 professional in the Costa Rican administration. ${ }^{37}$

- Daily cost of the institutional project co-ordinator: only projects lasting at least one month have co-ordinators, and the percentage of time devoted to the project is estimated in order to calculate this cost in relation to the co-ordinator's salary.

- Preparation time: this is determined by the expert, and is between three and five days. The daily salary for preparation work is lower than for implementation in the field (approximately 33\% of the daily salary), because it is assumed that preparation is not undertaken full-time.

Although no qualitative indicators are included, Costa Rica estimates the added value provided by the accumulated knowledge of the experts participating in the technical co-operation. The added value (professional history and accumulated experience) is a fixed quantity per activity (not per day or per project), which varies according to the expert's experience. For junior experts (between five and ten years of experience) it is estimated at USD 150. For experts with more than ten years of experience, it is estimated at USD 250. This "added value" is relatively innovative, as it is not used in the technical measurement methodologies of other countries studied in the TOSSD framework (such as Chile or Mexico).

Costa Rica has a certain amount of information about their projects, but as yet there is no systematic information on the direct and indirect cost of their experts applying this new methodology. Data collection should start in late 2018. This information has been requested, to allow for a broken down quantification of Costa Rica's technical co-operation according to the methodology approved by the TOSSD Task Force, and so that it can be included in TOSSD from 2019 onwards.

\subsubsection{Measurement of resources mobilised from the private sector}

Reporting on resources mobilised from the private sector is subject to specific rules regarding causality and methods of pro-rated attribution in order to avoid artificial inflation of the volume of TOSSD flows and double counting of these resources at the international level in cases where more than one official provider is involved in a project mobilising private finance.

To Costa Rican stakeholders' knowledge, there are no activities where resources are mobilised from the private sector. However, some of the stakeholders interviewed confirmed that, in some cases, this information is sent to the Costa Rican authorities. For instance, the EU confirmed that, in 2017, EUR 3.67 million had been mobilised leveraging a loan of EUR 121 million.

\footnotetext{
${ }^{37}$ In the Costa Rican administration, there are three job categories: technical, professional and managerial. Grade 3 is the highest grade in the professional category.
} 
Table 3. Estimates of resources mobilised from the private sector through external official interventions in Costa Rica, by provider and leveraging mechanism

USD million, 2012-15, current prices

\begin{tabular}{|c|c|c|c|c|c|c|}
\hline & $\begin{array}{l}\text { Syndicated } \\
\text { loans }\end{array}$ & Guarantees & $\begin{array}{l}\text { Equities and shares } \\
\text { in CIVs }\end{array}$ & $\begin{array}{l}\text { Direct investment in } \\
\text { companies }\end{array}$ & $\begin{array}{l}\text { Credit } \\
\text { lines }\end{array}$ & TOTAL \\
\hline $\begin{array}{l}\text { France - } \\
\text { Proparco }\end{array}$ & & & & & 4.7 & 4.7 \\
\hline IADB Group & 603.9 & & & & & 603.9 \\
\hline $\begin{array}{l}\text { Netherlands - } \\
\text { FMO }\end{array}$ & 15.2 & & & & & 15.2 \\
\hline Norway - Norfund & & & 2.4 & & & 2.4 \\
\hline $\begin{array}{l}\text { United States - } \\
\text { OPIC }\end{array}$ & & 76.6 & & 5.8 & & 82.3 \\
\hline TOTAL & 619.1 & 76.6 & 2.4 & 5.8 & 4.7 & 708.5 \\
\hline
\end{tabular}

Source: OECD (2018b), OECD (2019)

Note: CIVs: Collective Investment Vehicles

Table 4. Estimates of resources mobilised from the private sector through external official interventions in Costa Rica, by year and leveraging mechanism

USD million, 2012-15, current prices

\begin{tabular}{rcccccc}
\hline & $\begin{array}{c}\text { Syndicated } \\
\text { loans }\end{array}$ & Guarantees & Equities and shares in CIVs & $\begin{array}{c}\text { Direct investment in } \\
\text { companies }\end{array}$ & $\begin{array}{c}\text { Credit } \\
\text { lines }\end{array}$ & TOTAL \\
\hline 2012 & 22.0 & 19.5 & 2.0 & & & 43.5 \\
2013 & 559.7 & 39.8 & & & 599.4 \\
2014 & 8.5 & 7.3 & 0.4 & 5.8 & & 16.2 \\
2015 & 28.9 & 10.0 & & 4.7 & 49.4 \\
TOTAL & 619.0 & 76.6 & 2.4 & 5.8 & 4.7 & 708.5 \\
\hline
\end{tabular}

Source: OECD (2018b), OECD (2019)

Note: CIVs: Collective Investment Vehicles

Table 5. Estimates of resources mobilised from the private sector through external official interventions in Costa Rica, by sector and leveraging mechanism

USD million, 2012-15, current prices

\begin{tabular}{|c|c|c|c|c|c|c|}
\hline & $\begin{array}{l}\text { Syndicated } \\
\text { loans }\end{array}$ & Guarantees & $\begin{array}{l}\text { Equities and shares } \\
\text { in CIVs }\end{array}$ & $\begin{array}{l}\text { Direct investment in } \\
\text { companies }\end{array}$ & $\begin{array}{l}\text { Credit } \\
\text { lines }\end{array}$ & TOTAL \\
\hline Transport and storage & 13.7 & & & & & 13.7 \\
\hline Energy & 512.2 & & & 5.8 & & 518.0 \\
\hline $\begin{array}{l}\text { Banking and financial } \\
\text { services }\end{array}$ & 13.1 & 76.6 & & & 4.7 & 94.4 \\
\hline $\begin{array}{l}\text { Industry, mining, } \\
\text { construction }\end{array}$ & 80.0 & & 2.4 & & & 82.4 \\
\hline TOTAL & 619.0 & 76.6 & 2.4 & 5.8 & 4.7 & 708.5 \\
\hline
\end{tabular}

Source: OECD (2018b), OECD (2019)

Note: CIVs: Collective Investment Vehicles 


\section{TOSSD pillar 2: Global public goods}

In view of the holistic nature of TOSSD, the first discussions on the framework highlighted the possibility of taking into account contributions made not to a country, but resources invested at regional or global levels to contribute towards sustainable development. In practice, the measure would take into account contributions to (i) global and regional activities that would not give rise to cross-border flows, and (ii) relevant institutions in areas such as those shown in Figure 5 below.

Figure 5. Examples of development enablers and global challenges

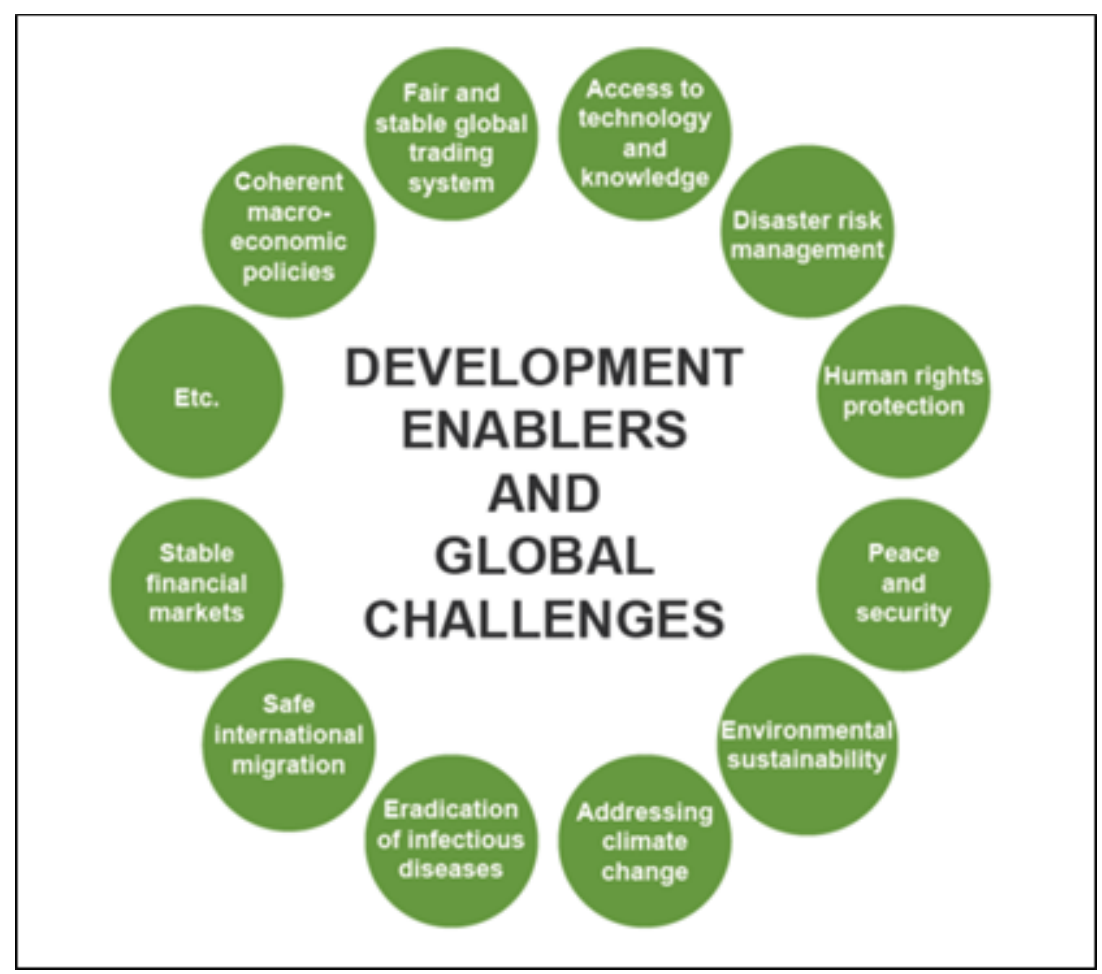

There were no specific comments about TOSSD Pillar II. Some respondents suggested that this pillar should have a holistic vision. 


\section{Reporting format, reporting cycle and detailed reporting instructions}

The main institutions collecting data on external development and their computerised data collection systems are as follows. As a recipient:

- MIDEPLAN's Co-operation Department: compiles information on financial co-operation and technical co-operation though the SIGECI (International Co-operation Project Management System). As regards information about what Costa Rica spends to implement the development co-operation received ("contrapartida"), the intention is to include a quantification of technical co-operation, including knowledge transfer (see Part III, Section 2.3.1, Measurement of technical co-operation). However, there are gaps for certain nonreporting ministries and independent organisations, including universities. For 2019 , it is also envisaged that a marker on external contributions of nonreimbursable financial and technical co-operation on climate change (adaptation and mitigation) is to be included within the climate finance framework, and the same for migration flows and refugees.

- MIDEPLAN's Investments Department: compiles public investment data within the DELPHOS system (for further information, see Part IV, Section 2.1.2., collection of data on loans). This information is publicly available. This platform has more than 80 variables.

- Ministry of Finance: compiles data on public investment with the SYGADE (External Debt Management System).

It should be pointed out that the DELPHOS and SYGADE systems are different and collect different types of information. To date, no harmonisation or co-ordination exercise has taken place between the two databases.

As a provider, data on in-kind technical co-operation is captured in the SIGECI system.

As regards knowledge and use of the IATI platform, most of the administration said that they were familiar with it. None of the stakeholders interviewed for this study said that they used data from IATI.

Concerning the reporting format and which parts of it could be covered, as a provider Costa Rica would be able to complete all the fields of the format for all the types of flows on which it collects information (no information is collected on mobilised private funds).Mapping against SDGs is done at target level, although some parts of the administration do not have all activities classified for all SDGs. In principle, there would be interest in and possibility of reporting on the SDG targets.

Classification by sector differs according to which part of the administration is reporting, but Costa Rica could use the sectoral classification proposed for TOSSD. Information on co-financing of investments is collected as far as the public sector is concerned.

As regards suggestions for additional fields, people interviewed proposed to add "national counterpart funding" for development projects, which could include both financial counterpart funding and monetisation of the counterpart provision of technical assistance. The country has devised a methodology to measure counterpart provision of technical assistance (see Annex B). There is also a field in the SIGECI database, where the external 
contribution (co-operation partners) and the local/national contribution (counterpart funding from institutions) are recorded. This would provide visibility on the efforts of TOSSD recipients. Likewise, the MIDEPLAN investment department includes the geographical location of projects, ${ }^{38}$ which gives citizens the opportunity to participate and increases accountability. It was suggested that the geographical location of projects also be added in TOSSD. One ministry also proposed that the implementing agencies should report on the administrative costs and experts' remuneration. Normally, co-operation partners do not provide a breakdown of these to Costa Rica and this information would be welcome. It was suggested that there should be a field 18.b, entitled "Of which administrative costs" as a subcategory of the total cost.

In terms of co-operation modalities, it was suggested that two different modalities should be included for South-South co-operation: bi-directional and traditional. In the former, there is a more or less balanced knowledge exchange, whereas in traditional co-operation one country transfers knowledge to another.

Lastly, it was suggested that the definition of channel of delivery should be clarified or two subcategories should be created. The current definition is hard to apply to the South-South co-operation modality, since the body responsible for implementation is not always the one that has responsibility over the funds. For example, when one agency manages the funds, but another is in charge of implementation. It was suggested that the definition should be clarified or two fields should be included: one for technical execution and the other for the administration of the financial resources.

${ }^{38} \mathrm{See}$ http://mapainversionescr.mideplan.go.cr. 


\section{Figure 6. Activity-level reporting form for TOSSD cross-border flows to developing countries}

\begin{tabular}{|c|c|}
\hline Reporting ltems & Clarifications \\
\hline \multicolumn{2}{|r|}{ A. Identification data } \\
\hline 1. Reporting year & Calendar year for which data are reported (e.g. reporting in 2019 on 2018 resource flows). \\
\hline 2. Provider country/institution & Each reporting country or multilateral institution has its own code. \\
\hline 3. Provider agency & $\begin{array}{l}\text { The provider agency is the government entity (central, state or local government agency or } \\
\text { department) financing the activity from its own budget. For multilateral organisations, it refers to } \\
\text { the department or fund financing the activity within the institution. The provider agency has budget } \\
\text { responsibility and controls the activity for its own account. }\end{array}$ \\
\hline 4. Provider project number & $\begin{array}{l}\text { The project number field facilitates tracking activities in provider institutions' internal databases } \\
\text { which may be necessary, for example, to respond to requests to verify the data regarding certain } \\
\text { reported activities. }\end{array}$ \\
\hline 5. TOSSD ID Number & $\begin{array}{l}\text { In addition to the provider project number, the TOSSD ID number is needed to ensure the } \\
\text { uniqueness of each transaction in the database and to link the original commitments and } \\
\text { subsequent disbursements over several years or between different components of the same } \\
\text { project. The format needs to be common to all providers. Set the ID at } 13 \text { digits, with the first three } \\
\text { digits equal to the provider country/institution code: e.g. for institution number } 901 \text {, the TOSSD ID } \\
\text { number would be } 901 \text { YYYYxxxxx. }\end{array}$ \\
\hline \multicolumn{2}{|r|}{ B. Basic data } \\
\hline 6. Project title & The official project title. \\
\hline 7. Description & $\begin{array}{l}\text { In English, French or Spanish (over time, the aspiration will be to collect this information in all UN } \\
\text { languages). }\end{array}$ \\
\hline 8. TOSSD recipient & Each recipient country has its own code. \\
\hline 9. Channel of delivery & $\begin{array}{l}\text { The channel of delivery is the first implementing partner. It is the entity that has implementing } \\
\text { responsibility over the funds and is normally linked to the provider agency by a contract or other } \\
\text { binding agreement, and is directly accountable to it. }\end{array}$ \\
\hline 10. Type of resource flow & $\begin{array}{l}\text { A distinction is made between official and officially-supported activities, i.e. resources mobilised } \\
\text { from the private sector. For financial transactions, a distinction is made between long-term and } \\
\text { short-term transactions. }\end{array}$ \\
\hline 11. Financial instrument & $\begin{array}{l}\text { A distinction is made between grants, debt instruments, mezzanine finance, equity and shares in } \\
\text { collective investment vehicles and guarantees and other unfunded contingent liabilities. [lslamic } \\
\text { finance to be developed.] }\end{array}$ \\
\hline 12. Modality & $\begin{array}{l}\text { A distinction will be made between various development co-operation modalities (to be } \\
\text { developed). }\end{array}$ \\
\hline 13. SDG focus (multiple choice) & $\begin{array}{l}\text { The "targets" as identified in the UNSC list of SDG targets (e.g. } 2.1 ; 3.3) \text {. Multiple choices will be } \\
\text { possible. In case no direct link can be found to an SDG Target, report the goal [and provide } \\
\text { justification for inclusion of the activity in TOSSD]. }\end{array}$ \\
\hline $\begin{array}{l}\text { 14. Sector/purpose code (multiple } \\
\text { choice) }\end{array}$ & Classification and codes to be discussed. \\
\hline 15. Co-financing arrangements & $\begin{array}{l}\text { Descriptive information, if applicable, on the broader co-financing arrangements such as the name } \\
\text { of the public and private co-financiers, the type of co-financing arrangements (syndication, } \\
\text { investment funds, project finance, etc.) and counterpart funding from the recipient government. }\end{array}$ \\
\hline \multicolumn{2}{|c|}{ C. Volume data (Amounts in thousands, to be adjusted in the light of some currencies if needed) } \\
\hline 16. Currency & Amounts are reported in the currency in which the transaction has been undertaken. \\
\hline 17. Amounts committed & New amounts committed during the reporting year, i.e. the face value of the activity. \\
\hline 18. Amounts disbursed & Amount disbursed during the reporting year. \\
\hline 19. Amounts received & $\begin{array}{l}\text { Covers recoveries on grants, amortisation of loans and gains or losses from equity sales (a } \\
\text { positive amount means that the provider country has made capital gains; a negative amount } \\
\text { means it has suffered capital losses). Amortisation relates to principal payments received from the } \\
\text { borrowing country during the reporting year, including any payments of arrears of principal. }\end{array}$ \\
\hline 20. Leveraging mechanism & $\begin{array}{l}\text { Indicates the leveraging instrument used, e.g. guarantee, syndicated loan, shares in collective } \\
\text { investment vehicles. }\end{array}$ \\
\hline 21. Amount mobilised & Report the amount of resources mobilised [following the methodologies in Annex]. \\
\hline 22. Origin of the funds mobilised & Distinguishes between funds mobilised in provider, recipient or third country. \\
\hline \multicolumn{2}{|l|}{ For loans only } \\
\hline 23. Maturity & Repayment period in months. \\
\hline
\end{tabular}




\section{Part IV. Costa Rica's perspective as a provider of development co-operation}

This part provides an overview of Costa Rica as a provider of development co-operation. The country has a dual role of provider and recipient of development co-operation. It provides in-kind technical co-operation, including triangular co-operation and incurs expenses for the sustenance of refugees and migrants within its borders. Moreover, it provides financial contributions to multilateral organisations, mainly assessed contributions, although it does not consider the latter as development co-operation. 


\section{Perspective on official flows}

The pilot study looked at Costa Rica's perspective as a provider of development cooperation. It should be noted that it would be important for Costa Rica to increase the visibility of its role as a dual co-operation partner. Portraying the country purely as a cooperation provider would be inaccurate.

The country views itself as a provider of technical co-operation only, because the financial contributions it makes to multilateral bodies take mainly the form of compulsory membership contributions. A significant proportion of the government is of the view that until those contributions have a visible impact in developing countries and are not used solely to finance the operating costs of the bodies in question, they cannot be regarded as development co-operation. Nonetheless, some government stakeholders interviewed were in favour of including them. The country would be willing to report these contributions under TOSSD for international data comparability, but would prefer to include metadata to explain their approach in the database.

Costa Rica does not have an army, however it contributes to peacekeeping operations such as those conducted by the United Nations, and could report contributions made in that regard.

It is also important to note that the fiscal crisis that Costa Rica is currently experiencing is making it difficult for the country to maintain South-South co-operation. Indeed, the government has had to forego implementing some South-South co-operation projects (funded under the shared costs method) due to a lack of funds, and many business trips and initiatives have been brought to a standstill for the same reason. Unless the situation is resolved, Costa Rica could once again become solely a recipient of co-operation. This is one of the factors that has prompted Costa Rica to establish a methodology to account for counterpart provision of technical co-operation (see Annex B) in an effort to make it clear that, despite the complex situation, Costa Rica is making a significant economic effort with respect to development co-operation. Thought has also been given to establishing a sustainable development fund in order to leverage additional resources to make it possible to finance South-South co-operation.

Triangular co-operation, whereby Costa Rica provides technical co-operation and another provider supplies the finance required to implement a project in a third country, is one method by which Costa Rica can continue providing technical co-operation to countries whose level of development is the same as or similar to its own. This method also enables the country to begin establishing alliances that go beyond the regional level, for example with Africa.

In addition to technical co-operation, which Costa Rica would have the capacity to report under TOSSD as a co-operation provider, Costa Rican universities are conducting publicly funded research initiatives that could be described as development enablers. However, under Costa Rican law, universities have full autonomy and do not report their co-operation projects to MIDEPLAN or any other body; such projects cannot be reported unless there is a change in the law.

Costa Rica makes in-country allocations to refugees and migrants, based on a human rights approach. Costa Rica views immigration as an opportunity that benefits the country and it provides support to the refugee population on grounds of international solidarity. In 
principle, Costa Rica could report these expenditures as of now and is willing to do so, but the country draws no distinction between refugees and non-refugee migrants. If the final TOSSD measure included only expenditures on refugees and not migrants in provider countries, MIDEPLAN's migration department would investigate whether the expenditures could be separated. The government says that, in view of fiscal constraints, financing this policy area is also a challenge, and they would need international aid to cast greater attention to it. There is a legal impediment, however: the migration department cannot accept funds from abroad unless they are managed by the providing agency. They can, however, accept grants in kind, for example staff supplied by UNHCR but selected by Costa Rica.

Finally, Costa Rica does not provide scholarships to other countries, although it would like to do so in the future, finance permitting, because the country is a staunch advocate of education as a means of social improvement.

Costa Rica has provided data on which to base estimates on Costa Rican flows as a provider. For 2018, it supplied data on administrative costs and contributions to UN bodies, including contributions to peacekeeping operations. No data have been supplied on refugees and humanitarian aid. Neither have data been supplied on South-South or triangular co-operation. This is because the country provides technical co-operation, and the methodology for measuring it is new and, therefore, there is yet no financial information available in that regard.

Estimated flows from Costa Rica as a provider in 2018 are USD 9.5 million, of which USD 9.3 million constituted contributions to multilateral bodies and USD 159000 administrative expenditures (see Annex D). 


\title{
2. Perspective on other cross-border flows that could be included as "satellite indicators": private investment, private philanthropy and remittances
}

\begin{abstract}
Although this is not the main focus of the pilot, the mission to the country also evaluated the potential to identify indicators beyond the TOSSD framework from the Costa Rican perspective. Those private resources could be considered "satellite indicators", which will not be part of the TOSSD framework but will provide interesting information of all types of flows for sustainable development.

The Central Bank of Costa Rica collects data on private FDI, philanthropic grants and remittances. That information is confidential and is published only in aggregate form with some disaggregation by country of origin and destination for remittances. Remittances and grants are recorded in the secondary income account of the country's current account. Data on remittances are estimated from surveys.
\end{abstract}

The main challenge facing the country to provide data on private investments is that, to date, there is no legal provision compelling businesses to provide data on those investments so that official statistics can be collated. Accordingly, it is very likely that the statistics collected are incomplete. The country is discussing amending the law to ensure that the national statistical system can compel businesses to provide this information.

One example of finance that includes public and private sources is the passenger train project in suburban San José in Figure 7.

Figure 7. Example of a complex financing arrangement: the project for a passenger train

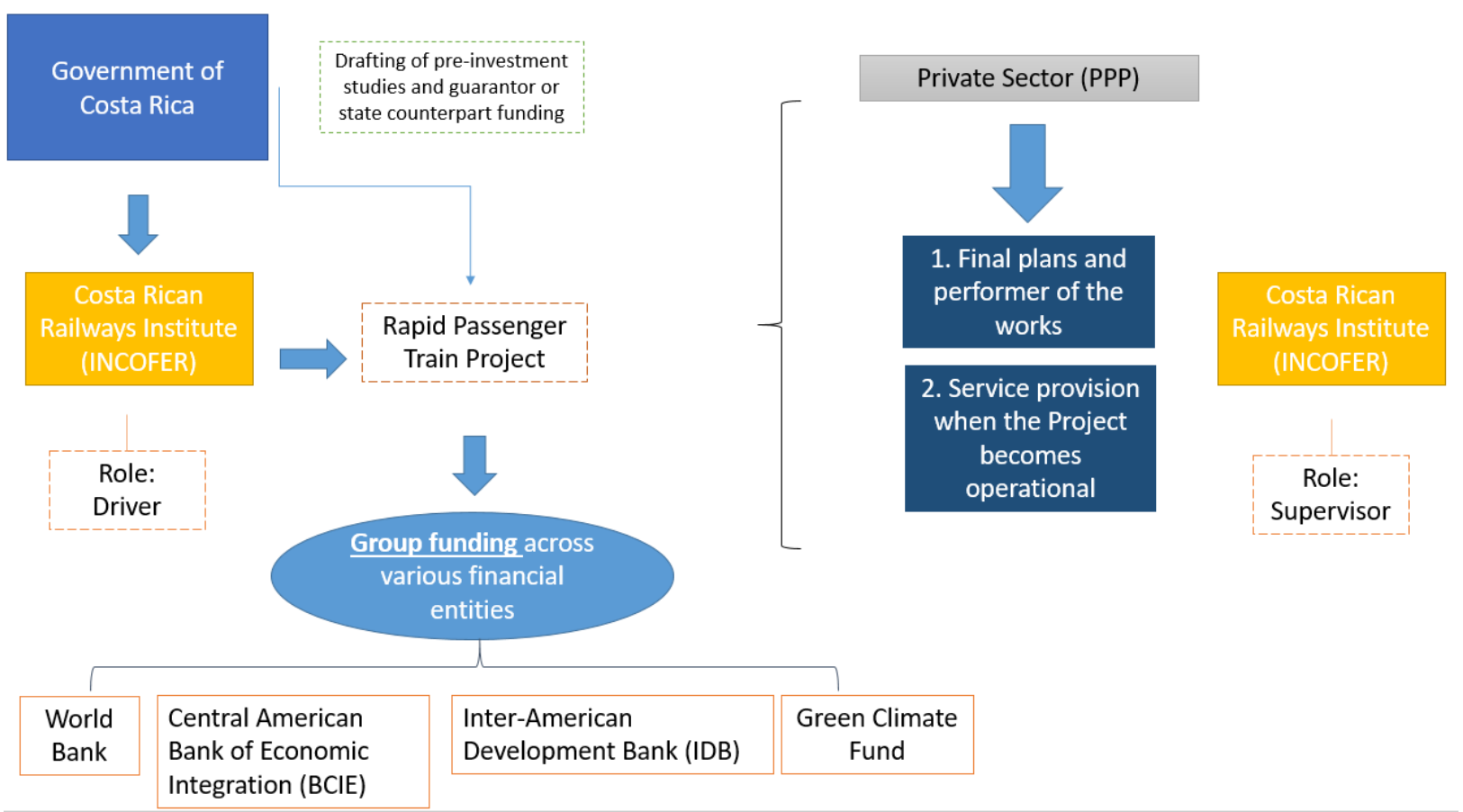

Source: MIDEPLAN, (2018) Unpublished 
Part V. Capacity assessment of the government of Costa Rica to access, collate, analyse and use official and private external flows

This section sets out the main findings of the capacity analysis in relation to each of the main challenges in the data management cycle for external resources for development finance. 


\section{Overview of the legal institutional architecture for development finance data}

Costa Rica has a "dual" role in development co-operation as set out in Article 11 of National Planning Law No. 5525 of 1974 and the amendments thereto, which states that it is the responsibility of MIDEPLAN to "[...] formulate, negotiate, co-ordinate, approve and evaluate technical assistance programmes, having regard to the objectives of the National Development Plan [...]". It further states that "[...] requests for technical assistance shall be forwarded by MIDEPLAN to the Ministry of Foreign Affairs, which shall assume responsibility for establishing that such requests are consistent with the country's foreign policy and shall duly present them to the relevant governments and international bodies."

The mechanism for cross-institutional co-ordination is shown in Figure 8.

Figure 8. Mechanism for cross-institutional co-ordination

\section{Mechanism for cross-institutional co-ordination: North-South Co-operation}

Advice, analysis, approval and registration under SIGECI

\section{Demand:}

International Co-op. Liaison System

Public-Sector Institutions and other stakeholders

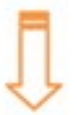

Official presentation and consistency with CR's For. Pol.

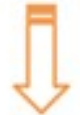

Int. Co-op. Dept

(MIDEPLAN)

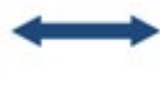

Int. Co-op. Dept

(Min. For. Rel.)

Formalisation

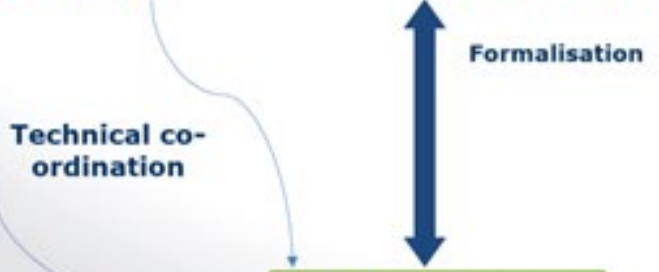

\section{Supply:}

Bilateral and

multilateral donors

Note: Double-headed arrows indicate official communications travel in both directions Source: MIDEPLAN (2018) Unpublished

Ministries and public-sector institutions (National Co-operation Subsystem) use an international co-operation liaison system to contact MIDEPLAN when they want to implement an international co-operation project. MIDEPLAN has two units in its cooperation department dealing with co-operation - one on bilateral and the other on multilateral co-operation. The bilateral co-operation unit is structured in turn by region (Europe, Asia/Oceania and the Americas); and the multilateral co-operation unit by type of body (European Union, the Inter-American System, the United Nations system and development banks). Finally, South-South and triangular co-operation are considered cross-cutting issues. 


\section{Figure 9. MIDEPLAN Organisational Structure}

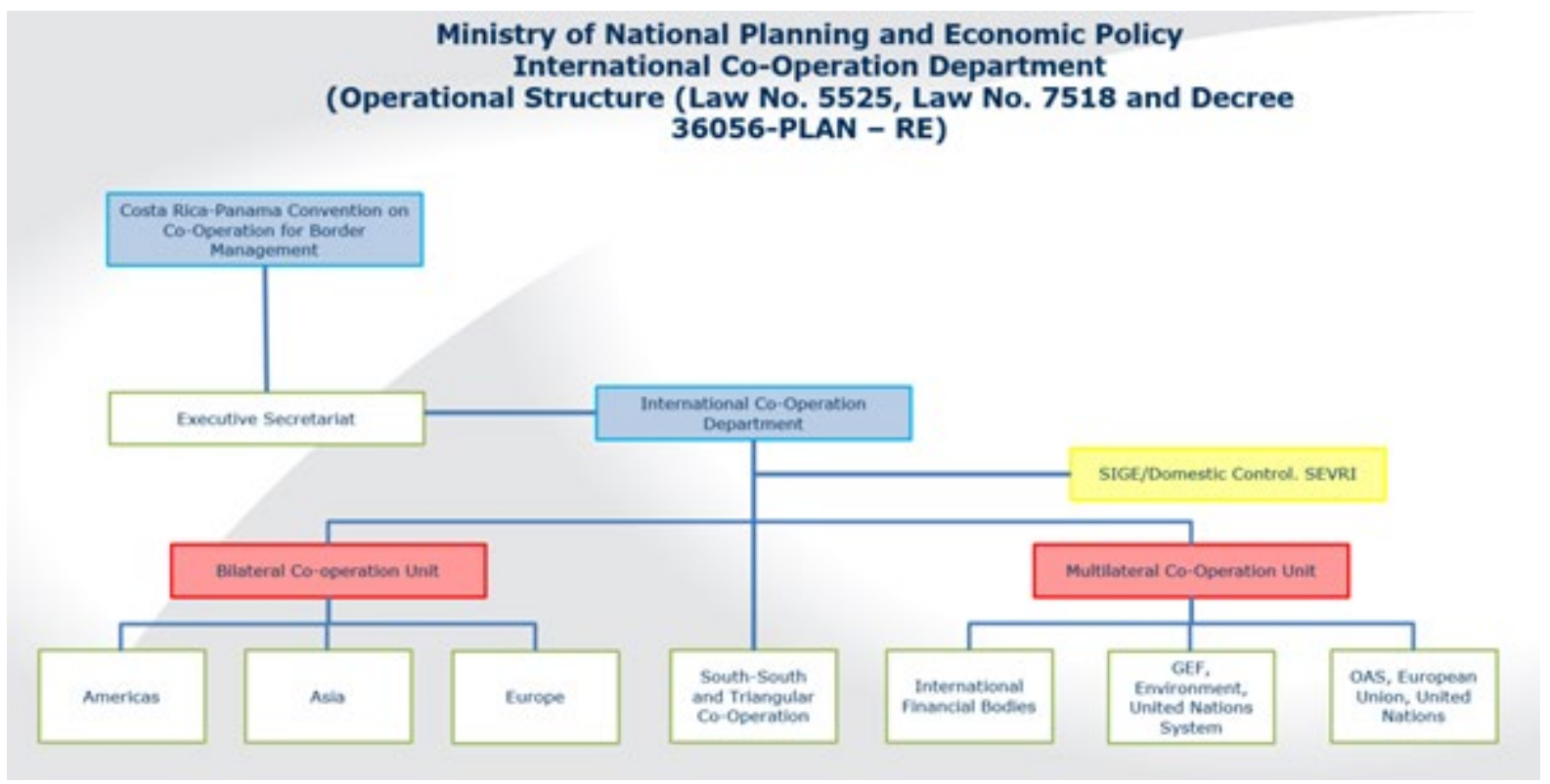

Source: MIDEPLAN (2018), Unpublished

A given project is analysed to see whether it is consistent with the PND. If it is judged to meet all the requirements for approval, it is then entered into the SIGECI platform. MIDEPLAN then forwards the project to the International Co-operation Department of the Ministry of Foreign Affairs for it to analyse whether the external aspects of the project are consistent with the country's foreign policy, and formalises it with the country's bilateral and multilateral co-operation partners.

For their part, the institutional liaison system and MIDEPLAN co-ordinate on a technical level with the bilateral and multilateral co-operation partners on drafting projects. The consequence of a system of this kind is extensive co-ordination between MIDEPLAN and the Ministry of Foreign Affairs.

In relation to reimbursable co-operation (investment projects), MIDEPLAN's investment department has responsibility for Costa Rica's national public investment system. It is separated into two units: pre-investment, which has a fund financing preliminary studies for large investment projects; and the public investment unit, which draws up public investment policies, guidelines and outlines.

The Treasury is responsible for public borrowing statistics and uses a different database than that of MIDEPLAN. These statistics can supplement figures for development co-operation. Statistics are collected on both concessional and non-concessional finance. On the one hand, the process generates a statistical and accounting record and, on the other hand, it tracks public investment projects in receipt of funding from multilateral bodies: disbursements, interest, local counterpart provision, etc. Both are available on the Ministry's website. ${ }^{39}$ Further details on data collection are provided in the next section.

Finally, the Treasury also makes, and collects information on, capital contributions to multilateral bodies.

\footnotetext{
${ }^{39} \mathrm{See} \quad$ https://www.hacienda.go.cr/contenido/14626-seguimiento-de-proyectos-financiados-con-endeudamientopublico.
} 


\section{Assessment of the capacity of the government of Costa Rica to manage development finance data}

\subsection{Capacity assessment on the collection of development finance information}

\subsubsection{Collection of data on grants and technical assistance}

Costa Rica has the information required and a system in place to collate data on disbursements (not commitments) of non-reimbursable co-operation, namely grants and technical assistance. However, the system is incomplete mainly because the law does not compel all stakeholders to report through the system.

The country collects data only in relation to disbursements. Pledges to Costa Rica are very volatile, and, in most cases, the country does not have information on donor pledges. Accordingly, as a recipient, the Costa Rican government is reactive rather than proactive and has little capacity to plan. The country appeals for funds only when a natural disaster occurs, but the commitments are very short term.

SIGECI does not collect all the grants received by the government. This is because, despite a requirement to report such funding, some national stakeholders fail to do so, even though MIDEPLAN reminds each government body that they are required to report and channel projects through MIDEPLAN. For example, during the interviews, it emerged that data on scholarships awarded are held at the Ministry of Foreign Affairs, but not reported to MIDEPLAN. The information is available and was forwarded on request $\left(\begin{array}{ll}1 & 163\end{array}\right.$ scholarships were received in 2016, 985 in 2017 and 402 up to 1 October 2018, but information on the amounts was not provided). Furthermore, during the interviews, it emerged that a series of projects conducted by INCOPESCA and technical co-operation delivered by AMEXCID that had not been registered into the system. Additionally, only national - not regional - data are collected, which results in the omission of a significant proportion of co-operation projects. This could be a result of a lack of co-ordination, or a lack of understanding on the part of certain bodies as to what is covered by "co-operation" (especially South-South co-operation), resulting in a failure to identify eligible activities falling under the co-operation umbrella.

Moreover, the law places no reporting obligation on a number of stakeholders who may also be involved in co-operation projects such as local governments, the universities, autonomous state agencies, NGOs and church organisations. The result is under-reporting in the SIGECI.

Private sector grants or loans are not currently collected in the SIGECI because the legal requirement applies only to bodies in the institutional liaison system, which are all in the public sector. The Business Alliance for Development (AED) expressed its willingness to work towards including data on their projects in SIGECI. We were informed that the Treasury has a list of bodies that are declared to serve a public purpose and receive cooperation funding, so this could provide a route to identifying the bodies in question and inviting them to register their projects. Two decrees have recently been drawn up to regulate public private partnerships (PPP) and public private partnerships for development (PPPD). The project was led by the Ministry of the Economy, Industry and Trade and the Office of the Second Vice-President. Last year, the Ministry of Foreign Affairs and Worship launched the national policy on corporate social responsibility, although there are still no 
regulations in place in that regard. It is expected that the creation of more PPPs and PPPDs and the progress in corporate social responsibility legislation will increase public private finance schemes and, in turn, provide information on private finance mobilised through official interventions.

Costa Rica is seeking to collect information on projects that are not strictly co-operation projects, where an international body manages the public funding (cost-sharing mechanism), for example UNOPS for infrastructure. The bodies in question do not contribute resources but earn a percentage for fund management, meaning they supply a paid service. Since this does not fit neatly into the traditional concept of development cooperation, a new module needs to be added to the SIGECI to record such projects into the platform. By contrast, other instances of projects in this category include counterpart provision and, as such, are regarded as co-operation; work is currently under way on how to reflect this concept in the SIGECI platform.

A new module will be incorporated into the SIGECI to manage climate finance. This is a result of an initiative currently being drawn up in co-operation with the German cooperation agency GIZ. The three aims of the project are to (i) identify the biodiversity funding gap; (ii) secure investment; and (iii) implement a strategy for mobilising resources to cover the gap. GIZ is working with MIDEPLAN, the Treasury and the Central Bank to investigate investment in climate change because it cannot be identified within the current budget structure. The work utilises the indicators set out under the United Nations Framework Convention on Climate Change. As referred to previously, Costa Rica does not have data on commitments; therefore, investments are identified from data on disbursements. Projects must be signed by the Office of the Controller General of the Republic; only the financial conditions are measured, and no analysis is made on the governance or political implications.

Finally, and as explained in section III, no data are available on in-kind technical cooperation provided by Costa Rica or the expenditures incurred in respect of refugees and migrants on Costa Rican territory. Costa Rica does not currently measure its technical cooperation, but will begin to do so from 2019. The migration department will also be able to collect information. Costa Rica does not include in the SIGECI system any information on contributions to multilateral bodies (although the information concerned is collected by the Treasury) because it is not seen as development co-operation. Publicly funded university research that falls within the scope of the development enablers pillar would be complex to quantify in view of the current legislation: the autonomy conferred upon universities means that they are not compelled to report in the way that other public bodies are.

\subsubsection{Collection of data on loans and other financial instruments}

Information on loans is fragmented and scattered across the government machinery: the National Concessions Centre (CNC) collects information in this regard; MIDEPLAN has an investment department; there is a public borrowing unit at the Treasury and a PPPs Office within the Treasury.

MIDEPLAN's investment department is responsible for Costa Rica's national public investment system and collects information on loans in a publicly accessible database. Similarly, the public borrowing department at the Treasury holds an Excel database, resulting in duplicated information and duplication of effort because the two databases are not mutually compatible. 
MIDEPLAN's investment department is separated into two units: pre-investment, which has a fund financing preliminary studies for large investment projects; and the public investment unit, which draws up public investment policies, guidelines and outlines.

MIDEPLAN's investment responsibilities also include gathering data on reimbursable resources and national budget resources. The data are collected directly from the institutions and entered into a platform called DELPHOS. The platform has three different modules that the public can access through the MIDEPLAN website: ${ }^{40}$

- Public Investment Projects Data Bank (BPIP). The various institutions are responsible for adding data, but MIDEPLAN verifies the quality of information before the projects are published. The module includes projects with different sources of finance: multilateral banks, development finance institutions (DFIs) and the national bank.

- Investment map: ${ }^{41}$ Map showing projects' locations. It has an additional module to encourage citizen's participation in official investment. It generates interaction: the public can fill in surveys, upload photographs, comment on progress in projects, etc.

- Losses incurred as a result of natural phenomena over the past 30 years: Information is held on all projects that were declared national emergencies. This module can identify the public investment losses generated by sector and by region. Disaster risk management has been mainstreamed here.

In order to ensure uniformity across reporting units, guidelines have been drawn up on how to enter information into the system. The database is updated daily with the data added by institutions and in September 2019 included over 2400 investment projects.

Having seen the TOSSD reporting format, the public investment unit confirmed that there is sufficient high-quality information for all fields, although it is neither streamlined nor in one place. In order to ensure that the information achieves the appropriate quality standards, it will be necessary to increase co-ordination at national level and to make sure that the information meets the requirements. MIDEPLAN would be the most appropriate institution to channel the information because of its greater data-mining capability; MIDEPLAN is willing to fulfil this role.

Additionally, a system named SYGADE within the public borrowing unit at the Ministry of Finance manages public debt statistics that flesh out the figures for co-operation. Much of the information is publicly available on the Ministry's website. ${ }^{42}$ The system records concessional and non-concessional finance, and there are two sources of records: first, a statistical and accounting record, and, second, tracking data for the public investment projects financed by multilateral bodies, data on disbursements, interest rates, local counterpart funding and all other forms of co-operation used to facilitate the project in question. A mature tracking system is in place to that end. Information on private finance is not collected as such; only information on the public share of PPPs' contingent liabilities is available.

\footnotetext{
${ }^{40} \mathrm{See}$ https://www. mideplan.go.cr/?option=com content\&view=article\&id=388.

${ }^{41} \mathrm{See}$ http://mapainversionescr.mideplan.go.cr.

${ }^{42}$ See $\quad$ https://www.hacienda.go.cr/contenido/14626-seguimiento-de-proyectos-financiados-con-endeudamientopublico.
} 


\subsubsection{Collection of data on private flows}

MIDEPLAN does not collect data on private finance leveraged by public interventions, although the European Union reports data on blended finance (strategic use of development finance to mobilise additional resources - mainly trade resources). The investment unit at MIDEPLAN could incorporate this information into its data collection system.

As noted above, decrees have recently been drawn up to regulate PPPs and PPPDs, but as instruments, they have not yet been used much and the country has no data on them. The only information collected comes from the $\mathrm{CNC}$ and relates to the financial structure of the project (by instrument). Data on private investment is not collected; indeed, private investment per se does not lie within its field of competence.

\subsection{Capacity assessment on the collation of development finance informationf}

The information on in-kind financial and technical co-operation is collected by MIDEPLAN and does not need to be collated because it is held in a single database. There are two parallel databases for reimbursable financial co-operation (public investment). Attempts made hitherto to streamline or merge them have not been successful.

MIDEPLAN's DELPHOS platform is attempting to link up with other government databases such as the national budget database and the database held by the Controller General's Office. Despite this, the investment units at MIDEPLAN and the Ministry of Finance have parallel databases that are not inter-linked and do not share information, making data collation difficult.

\subsection{Capacity assessment on the use and dissemination of development finance information}

Costa Rica makes the information it collects available to the public on the SIGECI platform ${ }^{43}$ and on DELPHOS, ${ }^{44}$ both of which are available at MIDEPLAN's website. SYGADE, ${ }^{45}$ the system that collects information on public borrowing, is also available to the public.

As referred to in Section 2.1.2, DELPHOS has a module that shows projects by geographical location in which the public can participate by adding information. There is also a module for losses caused by natural disasters, which is reportedly used extensively by academics.

Additionally, data is also disseminated in development co-operation reports.

As per the interviews held and the sources consulted, we can assess that Costa Rica is capable of using and disseminating the available data.

\footnotetext{
${ }^{43}$ Available at https://mideplan5-n.mideplan.go.cr/cooperacioninternacional.

${ }^{44}$ Available at https://www.mideplan.go.cr/?option=com content\&view=article\&id=388.

${ }^{45}$ Available at $\quad$ https://www.hacienda.go.cr/contenido/14626-seguimiento-de-proyectos-financiados-conendeudamiento-publico .
} 


\section{Conclusions and next steps}

The findings of this TOSSD pilot in Costa Rica have demonstrated that TOSSD can be useful to countries like Costa Rica that have planning tools but do not have a single system that draws together all the information they hold on external resources directed at implementing the 2030 Agenda in the country.

Additionally, TOSSD can boost resources directed at Costa Rica in support of sustainable development. This is necessary for an upper middle-income country because many donors have significantly cut their ODA. Moreover, if Costa Rica were to graduate from ODA, it could continue to receive TOSSD flows if it chose to follow the voluntary opt-in procedure.

Most of the concepts and classifications adopted by the TOSSD Task Force were confirmed in the pilot study, demonstrating that the concept is evolving appropriately. The interviewees gave recommendations on how to adapt the concepts and classifications to the situation on the ground in countries with a dual role as providers and recipients of development finance and the specific features of South-South co-operation. The findings of this pilot were discussed by the TOSSD Task Force at its meeting in Sweden in November 2018 and will help to refine the TOSSD Reporting Instructions that should be finalised in 2019.

Finally, the findings of this pilot will be shared at various international events and fora. Thanks to additional support provided by the European Union, another pilot study was undertaken in May 2018 in Nigeria, and TOSSD pilots will be conducted in the course of 2019 to further inform the work of the TOSSD Task Force and test the various parameters and methodologies of TOSSD. 


\section{Annex A. Overview of the interview process}

\section{Methodology used}

- The in-country mission drew primarily on semi-structured interviews based on an interview questionnaire.

\section{General flow of an interview}

- Introduction of the people participating in the interview.

- Explanation of the objectives of the study (based on the terms of reference).

- Interview: the questions asked were drawn from the list of questions in the interview questionnaire. In order to achieve the objectives of the study, other questions were asked in response to the replies given.

- Conclusion and follow-up: the interview ended with an explanation of the next steps (a study report).

\section{Additional questions not included in the questionnaire}

- Questions were asked as described in the interview questionnaire, but the OECD team did not hesitate to explore / seek clarification where necessary on certain aspects in response to the replies given by the interviewees in order to meet better the objectives of the mission.

- If a sensitive matter was raised during the interviews, interviewees could state that they would like certain matters not to be included in the report. 


\section{Annex B. Guide to determining the value of institutional counterpart funds in international co-operation projects}

This annex includes the guide to determine the value of institutional counterpart funding in international co-operation projects, as well as the value of in-kind technical co-operation provided by Costa Rica, as developed by MIDEPLAN.

\section{Glossary of terms and concepts used}

(a) Direct costs: the costs associated with the exchange of knowledge (flights, per diem allowances, in-country transport (fuel) and materials).

(b) Indirect costs: administrative support costs.

(c) Institutional Co-ordinator/ Director of the project: the person responsible for the project at the Costa Rican institution.

(d) Quantification of experience: an official's value based on experience and record in the field concerned.

(e) Indexed publications: a high-quality periodic research publication that is listed in a globally consulted database/index/series. In order to determine whether a journal is to be recorded in a database/index/series, certain quality indicators are taken into account. Although those indicators may vary across the different databases, generally speaking, they fall under the following headings:

\section{Quality of the research content}

- Members of editorial and scientific committees are identified.

- Authors are identified (forename, family name(s), affiliation).

- Content of the journal: a journal that includes a high number of original, unpublished articles, technical reports, seminars/talks to conferences and review articles is viewed positively.

- Detailed instructions to authors

- Articles accompanied by an abstract, if possible in at least two languages, keywords included.

\section{Technical or formal characteristics}

- Publication schedule for the journals, consistency and uniformity of the editorial line for book publishers. Publishing entity clearly stated.

- Anonymous manuscript review.

- The publisher or selection committee should include reasons for accepting, reviewing or rejecting the manuscript or the reports by external experts.

- An advisory council comprising established professionals and researchers that have no institutional links with the journal or publisher and is focused on setting, assessing and auditing editorial policy. 
- Use by the scientific community. An indicator that is often used in order to measure the use that the community makes of an article is the number of citations that it receives by other users, known as the "impact factor". It is commonly used to determine the visibility of an author, a discipline or a journal. http://bibliosjd.org/2018/03/13/revista-indexada/\#.Wz1HBtJKiUk

\section{Introduction}

Although the quantification of institutional counterpart funding in developing countries in receipt of international co-operation like Costa Rica is a work in progress, it is nonetheless necessary and increasingly pressing. It is vitally important to quantify and raise the visibility of in-kind resources contributed by institutions to each project, regardless of the type or method of contribution. Some countries have already made progress to this end, for example Chile, Mexico and Brazil, to name but a few. Each one has a different methodology, although they all have their similarities.

In view of the above, this Guide describes a blended methodology (to the extent that it has taken on board some input from the countries referred to as well as contributing ideas of its own in order to construct an initial tool enabling public institutions to account in a more rigorous and realistic way for the institutional contributions made to each international development co-operation project and programme.

International resources provided in response to a request should enhance, supplement and leverage national resources. Accordingly, the projects should focus on investment rather than operating expenditure.

Therefore, a guide has been produced to cater for the need for close complementarity between the country's technical and financial contributions, whether national, local or regional, and the contribution made by way of international co-operation.

All the projects financed using non-reimbursable external resources should provide for institutional counterpart funding, and, in order to calculate the amount of such funding, this guide sets out the variables to consider, the headings under which each one falls and the respective calculations. This guide applies to bilateral and multilateral South-South and triangular co-operation projects.

This Guide is compulsory for all Costa Rican public-sector institutions and is based on the regulations governing the management of International Co-operation, in particular the following sections of Executive Decree 35056-PLAN-RE:

\section{CHAPTER II}

Oversight and Non-Reimbursable International Co-operation Bodies

SECTION I

Functions of MIDEPLAN and the Ministry of Foreign Affairs

Article 3 - Functions of MIDEPLAN.

MIDEPLAN shall be responsible for domestic aspects of international co-operation matters and shall have exclusive competence in the management and technical negotiation of such co-operation with national entities, bodies and institutions in order to ensure that the 
international co-operation in question is consistent with the National Development Plan. Its functions in international co-operation matters are as follows:

(Previous paragraph as amended by Article 1 of Executive Decree 35777 of 8 January 2010.)

(c) To co-ordinate the process of managing non-reimbursable international co-operation by agreeing the means and effort necessary in order to secure resources in accordance with the priorities identified in the National Development Plan. In order to perform this task, it shall work with the Ministry of Foreign Affairs and the International Co-operation Liaison System.

(d) To advise public entities on the formulation of international co-operation proposals and the management process in its entirety.

\section{VARIABLES AND FORMULA}

\subsection{VARIABLES TO BE TAKEN INTO ACCOUNT}

The following variables must be used to account for the institutional counterpart funding by Costa Rica in bilateral and multilateral South-South and Triangular Co-operation projects.

a. Direct costs:

- Flights

- Accommodation

- Subsistence

- In-country transport (fuel)

- Materials

b. Indirect costs:

Institutional administrative support for a project as quantified by the Costa Rican institution. This comprises various procedures, physical space, computing equipment, water, electricity, telephone, printing, Internet, vehicle use and secretarial support.

\section{c. Daily cost of an Expert Professional:}

The daily average of the monthly salary of the Costa Rican official assigned to work on an international co-operation project.

\section{d. Daily cost of the Institutional Project Co-ordinator/Director: ${ }^{46}$}

\footnotetext{
${ }^{46}$ The institutional official responsible for implementing the project on the Costa Rican side.
} 
The daily average of the monthly salary of the Costa Rican official appointed to act as project co-ordinator; applies when applicable.

\section{e. Preparation days:}

The estimated number of days required to prepare for a specific scheduled project activity. Between three and five days' preparation ${ }^{47}$ are allowed for each activity throughout the project implementation phase. To be quantified only for South-South and Triangular Cooperation projects. For experts in North-South Co-operation projects, it applies only if they are to hold workshops, discussions or conferences.

For traditional (bilateral or multilateral) projects, it will apply only to expert professionals and not to the institutional co-ordinator/director of the project.

\section{f. Record and experience gained:}

The quantification of an institutional official's cumulative value, experience and record in the field concerned. There are two (2) possible categories: Junior or Senior.

The junior category requires:

- Between 5 and 10 years' work in the project field.

The senior category requires:

- More than 10 years' work in the project field.

- Acting as the representative of the institution in the field concerned at national and international level.

- Publication of various papers in the subject area (preferably indexed publications).

\subsection{EXPLANATORY NOTES TO THE VARIABLES}

a. Variables that must always be taken into account when calculating counterpart funding are: indirect costs, expert professionals' hours, monthly salary of the institutional project co-ordinator (where applicable), preparation days, record and experience.

b. The direct costs are calculated with reference to institutional data; accordingly, the administrative/financial units of the institutions must be consulted. If these costs are borne by the co-operation partner(s), they are not accounted for as counterpart funding.

c. Value added is applied once in respect of the co-ordinator for each year of project implementation.

\footnotetext{
${ }^{47}$ The expert official will determine the time required to prepare the activity(ies).
} 
If the project duration is less than one year, it applies once in respect of the co-ordinator for each month of the project, and in respect of the expert, for each activity performed.

Value added is calculated with respect to two (2) categories: Junior and Senior. Each category has a different cost (See Table).

d. The average monthly salary of an expert professional is USD 3400 (CRC 2 million as an average). Equivalent to USD 115/day for experts at current exchange rates.

e. The monthly salary of an institutional project co-ordinator is USD $5257^{48}$ (CRC 3 million as an average). The exchange rates will be updated each time a project is drawn up.

f. Administrative support (indirect costs). A rate of 5\% is applied to the total institutional counterpart funding for South-South or Triangular Co-operation projects and a rate of $7 \%$ is applied to traditional bilateral or multilateral projects.

g. The activities conducted by the expert can include workshops, discussions, technical meetings, document review, field missions and visits, or tailored technical consultations, among others.

\subsection{BUDGET}

For the purposes of the budget, a budget item under the heading "Technical Contribution" will be included, comprising:

- indirect costs,

- hours given by expert professionals,

- the salary of the Institutional Project Co-ordinator,

- the preparation days required by the experts, and

- value added.

The sum of those figures equals the Institutional Technical Contribution.

The other variables, namely the individual direct costs will be listed as follows:

- flights,

- per diem allowances (subsistence and accommodation),

- in-country transport, and

- equipment and supplies.

Indirect costs are calculated at a rate of $5 \%$ or $7 \%$ (depending on the type of co-operation) of the sum of those variables (see examples). The final sum of those amounts equals the amount of institutional counterpart funding.

IMPORTANT: MIDEPLAN SIGECI records state only the total amount of the institutional counterpart funding.

\footnotetext{
${ }^{48}$ Official exchange rate of sale of CRC 570.65 = US\$1 at 26 June 2018.
} 
Table A B.1. Variables and corresponding amounts in US dollars

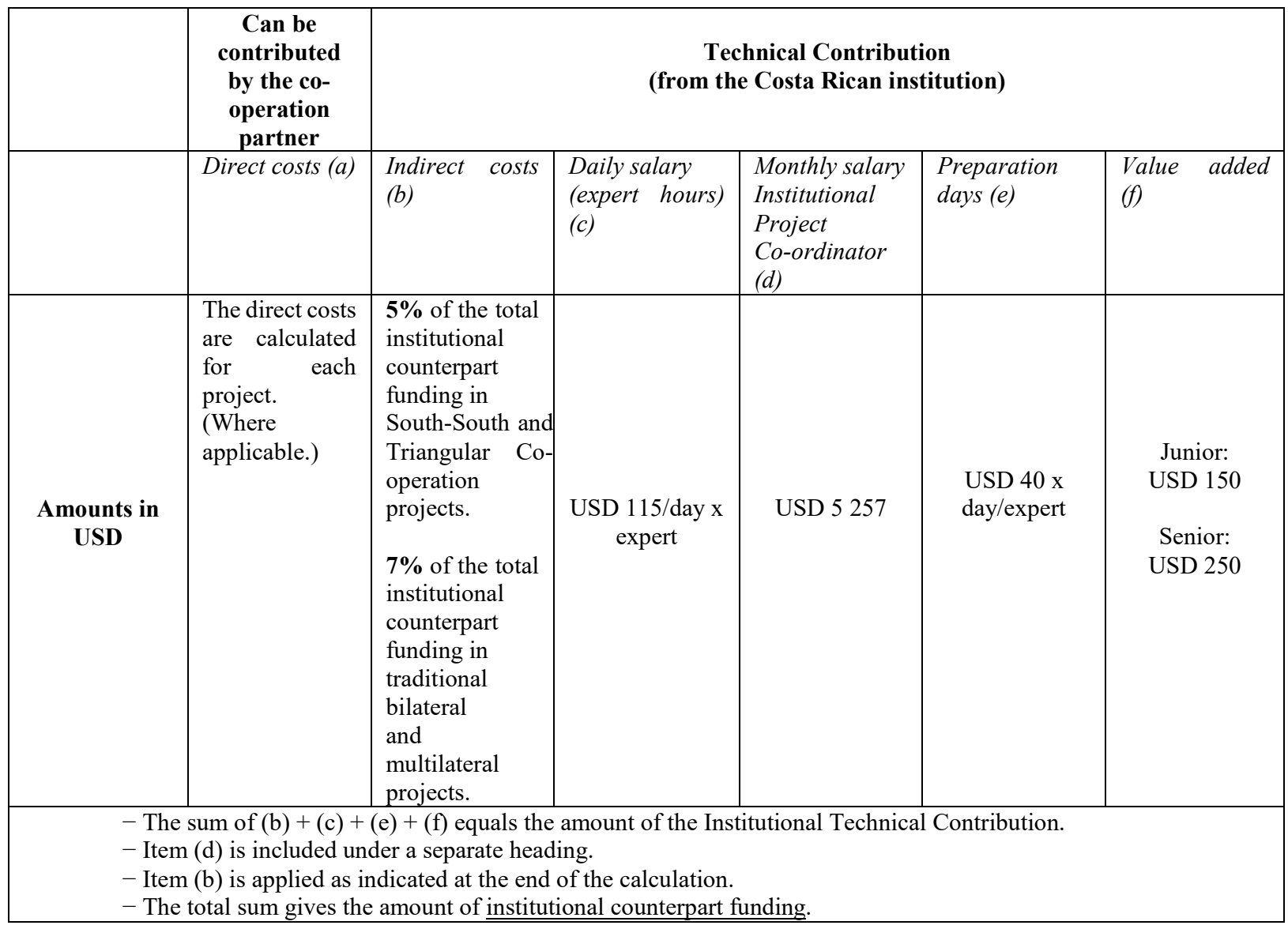

\section{BUDGET EXAMPLE FOR COUTNERPART FUNDING IN A SOUTH-SOUTH AND TRIANGULAR CO-OPERATION PROJECT}

Budget example, by item and body

(In US dollars)

\begin{tabular}{|c|c|c|c|c|}
\hline Items & $\begin{array}{c}\text { Costa Rica } \\
\text { (SINAC) }\end{array}$ & Germany (GIZ) & $\begin{array}{c}\text { Mexico } \\
\text { (AMEXCID) }\end{array}$ & Total \\
\hline $\begin{array}{c}\text { Institutional project co-ordinator x } \\
24 \text { months, } 1 / 2 \text {-time, @ USD 2 628.50/month. }\end{array}$ & USD 75 584 & & & \\
\hline-1 senior expert x 6 activities (workshops) & 2735 & & & \\
\hline Flights & & USD 10 000 & & \\
\hline Per diem allowances & & USD 15 000 & USD 5 000 & \\
\hline In-country transport & & USD 2 000 & \\
\hline Logistics & & USD 15 000 & USD 2 000 & \\
\hline Processing & & USD 20 000 & & \\
\hline Assessment & & USD 60 000 & USD 9 000 & \\
\hline Total & USD 82 084 & $\mathbf{4 9}$ & &
\end{tabular}

* A 5\% rate is applied by way of indirect costs as this is a Triangular Co-operation project.

\footnotetext{
${ }^{49}$ Includes $5 \%$ of the total institutional counterpart funding. Amount that should appear in the MIDEPLAN SIGECI.
} 


\section{Calculation of institutional counterpart funding:}

a. Project co-ordinator:

$1 / 2$-t: USD 5257 (monthly salary) divided by $2=$ USD 2628.50

$\mathrm{x}(2$ years $) 24$ months $=$ USD 69084

+ USD $250(\mathrm{VA})$

$=$ USD 75584

b. Senior expert:

1 expert at USD 115 (daily salary) $\mathrm{x} 9$ days of workshops in total (equivalent to 6 activities)

$=$ USD 1035

+20 days of preparation in total $=$ USD 800

+ USD 150 (VA) x 6 activities = USD 900

$=$ USD 2735

$+5 \%$ indirect (administrative) costs

$=$ USD 3765

Total counterpart funding: USD 82084

\section{BUDGET EXAMPLE FOR COUNTERPART FUNDING IN A BILATERAL CO-OPERATION PROJECT}

Budget example, by item and body

(In US dollars)

\begin{tabular}{|c|c|c|}
\hline Items & Costa Rica & Germany (GIZ) \\
\hline $\begin{array}{l}1 \text { project director x } 24 \text { months } \\
\text { f/t @ USD } 4000 / \text { month. }\end{array}$ & & USD 96000 \\
\hline $\begin{array}{c}1 \text { institutional project co-ordinator x } 1 / 2-\mathrm{t} @ \text { @ USD } 2628.50 \times 24 \\
\text { months }\end{array}$ & USD 75584 & \\
\hline $\begin{array}{l}\text { - } 3 \text { junior experts x } 12 \text { months @ USD 115/day+ USD 150(VA) x } 3 \\
\text { - } 1 \text { senior expert x } 12 \text { months @ USD 115/day + USD } 250 \text { (VA) }\end{array}$ & $\begin{array}{l}\text { USD } 62500 \\
\text { USD } 20950\end{array}$ & \\
\hline Facilitators for 10 workshops & & USD 40000 \\
\hline Workshop logistics & & USD 20000 \\
\hline Printing and materials & & USD 10000 \\
\hline Flights and per diem allowances & & USD 15000 \\
\hline In-country transport & USD 5000 & \\
\hline Final assessment & & USD 30000 \\
\hline Total & USD $175516^{50}$ & USD 211000 \\
\hline
\end{tabular}

NB: The dollar calculation uses the official exchange rate at the time of writing.

\section{Calculation of institutional counterpart funding:}

a. Project co-ordinator:

1/2-t: USD 5257 (monthly salary) divided by $2=$ USD 2628.50

$\mathrm{x}$ (2 years) 24 months $=$ USD 69084

+ USD 250 (VA)

$=$ USD 75584

b. Junior experts:

3 experts @ 1/2-t: USD 115 (daily salary) divided by 2 =USD 57.50

x 12 months (30 days $x 12$ months) = USD 20700

$\mathrm{x} 3$ experts $=$ USD 62100

${ }^{50}$ Includes $7 \%$ applied to the total. Total institutional counterpart funding. 
+ USD 150 (VA) x 3

$=$ USD 62500

c. Senior expert:

1 expert @ 1/2-t: USD 115 (daily salary) divided by 2 =USD 57.50

x 12 months (30 days x 12 months) = USD 20700

+ USD 250 (VA)

$=$ USD 20950

d. In-country transport

Calculated using data from governmental sources on per diem allowances for chauffeuring and petrol $=$ USD 5000

$\underline{\text { Sum total: USD } 164034}$

$+7 \%$ by way of indirect (administrative) costs

$=$ USD 11482

Total counterpart funding: USD 175516 


\section{Annex C. List of institutions interviewed for the pillot TOSSD in Costa Rica}

Business Alliance for Development (AED)

Central Bank of Costa Rica (BCCR)

Costa Rican Chamber of Commerce (AMCHAM)

Costa Rican Investment Promotion Agency (CINDE)

The Costa Rica-United States Foundation for Cooperation (CR-USA Foundation)

Embassy of the People's Republic of China

Embassy of Mexico

European Union

\section{FUNDECOOPERACION}

INCOPESCA (Costa Rican Fisheries Institute)

Ministry of Agriculture and Livestock (MAG)

Ministry of Coordination and Liaison with Productive Sector

Ministry of the Environment and Energy (MINAE)

Ministry of External Trade (COMEX)

Ministry of Finance

Ministry of Foreign Affairs

Ministry of the Interior and Police

Ministry of National Planning and Economic Policy

Ministry of Public Works and Transport (MOPT)

Ministry of Relations with the Productive Sector

National Concessions Council (CNC)

Presidential House

Spanish International Development Co-operation Agency (AECID)

United Nations Resident Co-ordinator office 


\section{Annex D. Estimation of flows of Costa Rica as a provider}

\begin{tabular}{lc} 
& $\begin{array}{c}2018 \text { (USD) } \\
\text { Disbursements }\end{array}$ \\
\hline Refugees & Info not available \\
$\begin{array}{l}\text { Humanitarian Assistance } \\
\text { Administrative Costs }\end{array}$ & Info not available \\
$\begin{array}{l}\text { Contributions to international organisations, including peacekeeping } \\
\text { operations }\end{array}$ & $159,199.52$ \\
$\begin{array}{l}\text { South-South and Triangular Co-Operation } \\
\text { Scholarships }\end{array}$ & $9,344,056.28$ \\
TOTAL & Info not available \\
& Non applicable \\
\hline & $\mathbf{9 , 5 0 3 , 2 5 5 . 8 1}$
\end{tabular}

Detail of contributions to international organisations

2018

Description

Disbursements

(CR Colon)

Forum of Central American Legislative Presidents (Foprel).

14570000

World Inter-Parliamentary Union.

12152000

Parlamericas.

2480000

Parliamentary Confederation of the Americas (Cup).

3100000

Latin American and Caribbean Organization of Supreme Audit Institutions.

5122000

International Organization of Supervising Entities - Intosai.

289000

Global Alliance of National Institutions in Human Rights (Ganhri)

3000000

International Committee of the Red Cross. (Cicr).

17477460

International Organization for the Prohibition of Nuclear Weapons in Latin America and

1966200

United Nations. (Onu)

695041278

United Nations Development Program.

120000300

United Nations Development Program. (Pnud).

198336000

Organization of American States. (Oea) (Office of the Pan-American Union in Costa Rica).

16063200

Organization of American States. (Oea Regular Fund).

144644460

Pan-American Institute of Geography and History. (Ipgh)

3249310

Secretariat of Ibero-American Cooperation. (Secib).

13005900

Office of the Special Rapporteur for Freedom of Expression of the Inter-American Court of

1763460

Association of Caribbean States. (Aec).

29202960

Onu - Maintenance Of Peace And International Courts.

458268273

United Nations. (Onu) (Group Of 77).

2927460

International Organization for Migrations. (Office In Costa Rica).

4110085

Organization of the Comprehensive Nuclear Test Ban Treaty. (Ctbto)

37520725

Fund Committee on the Limits of the Continental Shelf.

3019300 
University for Peace.

29100000

Convention on the Prohibition of Antipersonnel Mines.

3218460

Biological Weapons Convention.

291000

Inter-American Commission on Human Rights. (Cidh)

5820000

Organization for Economic Cooperation and Development (Ocde).

9783484

World Customs Organization.

15173952

Organization for Economic Cooperation and Development (Ocde).

12222000

United Nations Organization for Agriculture and Food (Fao).

98376414

Inter-American Institute of Cooperation for Agriculture (IICA).

40158000

Pan-American Dairy Federation (Fepale).

United Nations Organization for Industrial Development (Onudi).

1746000

Center for the Promotion of Micro and Small Enterprises in Central America (Cenpromype).

52181400

Organization for Economic Cooperation and Development (OECD).

20370000

Secretary of Central American Economic Integration (Sieca).

7930000

World Road Association (Piarc).

21433125

2455722

Latin American Faculty of Social Sciences (Flacso) Academic Headquarters in Costa Rica.

17460000

Central American Institute of Public Administration (Icap).

104760000

Organization of Ibero-American States (Oei).

Subregional Office of Education for Latin America Oreal / Unesco Santiago.

20227410

11058000

Central American Educational and Cultural Coordination - Cecc

12611940

World Health Organization (Oms).

World Health Organization (Oms).

8200000

Pan American Health Organization (Ops).

Council of Ministers of Health of Central America.

102675558

$123 \quad 670684$

International Atomic Energy Agency (Oiea).

26979750

15015000

Institute of Nutrition of Central America and Panama (Incap).

29317680

Ibero-American Social Security Organization (Oiss).

29362197

Iberrutas Program.

7566000

17460000

Iberoamerican Program Of Ibermuseum Museums

568032

Ibero-American Culture Program (Ibercultura).

14550000

Association of Ibero-American National Libraries (Abinia).

2007900

Latin American Institute for the Prevention of Crime and the Treatment of Offenders

389032000

Organization for Economic Cooperation and Development (OECD).

8975000

World Intellectual Property Organization (Ompi).

3500000

Permanent Secretariat of Central American Economic Integration (Sieca).

291000000

Organization for Economic Cooperation and Development (OECD).

58000000

Latin American Center for Development Administration. (Clad)

13000000

Organization for Economic Cooperation and Development (OECD).

7700000

Organization for Economic Cooperation and Development (Ocde).

9100000

International Union for the Conservation of Nature and Natural Resources (UICN).

9661200

Central American Commission on Environment and Development (Ccad).

11640000

United Nations Framework Convention on Climate Change.

4248600

National Marine Sanctuary Foundation.

1164000

United Nations Program for the Environment (UNEP).

1280400 
5080 Cos. Foundation

3510042

United Nations Program for the Environment (UNEP).

1366536

Inter-American Institute for Global Change Research.

2910000

Latin American Energy Organization (Olade).

15534634

Association of High Administrative Jurisdictions. (Affiliation Fee According to Full Court

707680

Commission of Venice of the Council of Europe (for Payment of Membership Fee

3007713

Latin American Faculty of Social Sciences (Flacso) Academic Headquarters of Costa Rica.

15000000

Latin American Parliament.

International Organization for Migrations. (Omi)

18600000

Instituto Italo Latinoamericano. (Iila)

11660370

Organization for the Prohibition of Chemical Weapons.

3766460

International Court of Law of the Sea

Latin American Faculty

Central American Integration System. (Sica)

20787850

4447560

54999000

180127780

High Commissioner for Human Rights.

5837460

International Criminal Court.

Hague Conference on Private International Law. (Cohadip)

75913345

Convention on the Prohibition of Cluster Munitions.

3363960

International Cocoa Organization (Icco).

3704730

4011260

International Maritime Organization (OMI).

Inter-American Committee on Ports (CIP) Organization of American States

6310000

3492000

United Nations Organization for Education Science and Culture (Unesco).

89062993

Organization for Economic Cooperation and Development-OECD

31679910

United Nations Program for the Environment (UNEP).

1337328

United Nations Children's Fund in Costa Rica (Unicef).

10470972

Cecc / Sica Cultural Education Coordinator.

5820000

Regional Center for the Promotion of the Book in Latin America (Cerlac-Unesco).

4539600

Ibero-American Program for the Preservation of Sound and Audiovisual Heritage

2910000

International Atomic Energy Organization

Regional Telecommunications Technical Commission (Comtelca).

72300000

22000000

Environmental Information Network for Latin America and the Caribbean.

2910000

United Nations Program for the Environment (UNEP).

1455000

Program for the United Nations for the Environment (UNEP).

2037000

United Nations Program.

2328000

International Whale Commission.

10883400

Organization for Economic Cooperation and Development (OECD).

5820000

International Institute Of Democracy And Electoral Assistance (Idea).

3100000

World Association of Electoral Organizations (A-Web by its acronym in English).

6200000

High Commissioner of the United Nations for Refugees. (UNHCR).

8730000

United Nations Population Fund.

2894400

81000000

United Nations Development Program.

58200000

Inter-American Court of Human Rights.

1769280

International Seabed Authority.

4074000

Inter-American Institute of Human Rights.

5238000

National Section of the Pan American Institute of Geography and History. (Ipgh - Cr). 
Permanent Court of Arbitration. $\quad 734485$

International Humanitarian Survey Commission. $\quad 122450$

Convention on Certain Conventional Weapons. $\quad 308460$

Council of Finance Ministers or Finance of Central America Panama and the Dominican $\quad 18333333$

Inter-American Center of Tax Administration (Ciat). $\quad 30092892$

Organization for Economic Cooperation and Development (OECD) $\quad 32803441$

Ibero-American Association of Fiscal or Administrative Justice Courts. $\quad 582000$

Tropical Agricultural Research and Teaching Center (Catie). $\quad 29100000$

Central American Agricultural Council (Cac). $\quad 26190000$

Organization for Economic Cooperation and Development (OECD). $\quad 7930000$

Central American Commission of Maritime Transport (Cocatram). $\quad 1746000$

Unesco Surregional Office for Central America and Panama. $\quad 52803696$

International Labor Organization (OIT).

101513468

Ibero-American Social Security Organization (Oiss).

5219801

United Nations Development Program (UNDP)

70000000

$\begin{array}{lr}\text { United Nations Organization for Education Science and Culture (Unesco). } & 587820 \\ \text { Latin American Economic System (Sela). } & 6431 \quad 80\end{array}$

Iberoamerican Program of Public Libraries (Iberibibliotecas). $\quad 8730000$

World Trade Organization (Omc). $\quad 88000000$

International Center for Settlement of Investment Disputes (ICSID). $\quad 320650000$

Latin American and Caribbean Institute of Economic and Social Planning. Economic 27000000

International Telecommunications Union (Uit). $\quad 44500000$

International Union for the Conservation of Nature (Uicn). $\quad 1169238$

United Nations Program for the Environment (UNEP). $\quad 8099694$

United Nations Program for the Environment (UNEP). $\quad 8148000$

World Meteorological Organization (Omm). $\quad 19791492$

Regional Committee of Hydraulic Resources. $\quad 24007500$

International Criminal Police Organization (Interpol). (For Payment of Membership Fees 30000000

Inter-American Institute of Human Rights. $\quad 3100000$

5302873412

Exchange rate Costa Rica Colon / USD 2017 OCDE (latest available)

567.513

USD

9344056.28 


\section{References}

Aid Data (2018) China's profile, Aid Data Washington DC, retrieved from https://china.aiddata.org.

Benn, J., et al. (2016), "Amounts Mobilised from the Private Sector by Official Development Finance Interventions: Guarantees, syndicated loans and shares in collective investment vehicles", OECD Development Co-operation Working Papers, No. 26, OECD Publishing, Paris, https://doi.org/10.1787/5jm3xh459n37-en.

Benn, J., C. Sangaré and T. Hos (2017), “Amounts Mobilised from the Private Sector by Official Development Finance Interventions: Guarantees, syndicated loans, shares in collective investment vehicles, direct investment in companies, credit lines", OECD Development Co-operation Working Papers, No. 36, OECD Publishing, Paris. http://dx.doi.org/10.1787/8135abde-en and tools for data visualisation.

ECLAC (2016) El enfoque de brechas estructurales: Análisis del caso de Costa Rica

Santiago de Chile, ECLAC Santiago de Chile, https://www.cepal.org/es/publicaciones/40805-enfoque-brechas-estructurales-analisiscaso-costa-rica

Delalande G. and V. Gaveau (2018) "Senegal's perspective on TOSSD" OECD Development Co-operation Working Papers No. 43 OECD Publishing Paris http://dx.doi.org/10.1787/4144f82a-en

Delalande G. Et al. (2018) "Nigeria's Perspective on Total Official Support for Sustainable Development (TOSSD)" OECD Development Co-operation Working Papers No. 50 OECD Publishing Paris https://doi.org/10.1787/619cb021-en.

Delalande G. R. Halvorson-Quevedo and C. Sangaré (2018) “The Philippines' perspective on TOSSD" OECD Development Co-operation Working Papers No. 42 OECD Publishing Paris http://dx.doi.org/10.1787/6ecaa5ac-enS.

EIU (2018): Country Forecast July 2018: Costa Rica, https://store.eiu.com/product/country-report/costa-rica.

European Commission (2018): International Co-operation and Development: Costa Rica, https://ec.europa.eu/europeaid/countries/costa-rica_en.

Global Financial Integrity (2017), Global Financial Integrity, Washington DC. http://www.gfintegrity.org/wp-content/uploads/2017/05/GFI-IFF-Report-2017 final.pdf

IMF (2018): Costa Rica 2017 - Article IV Consultation, IMF Washington DC, https://www.imf.org/en/Publications/CR/Issues/2017/06/27/Costa-Rica-2017-Article-IVConsultation-Press-Release-and-Staff-Report-44991.

NDC (2017): Country Outlook: Costa Rica, https://ndepartnership.org/sites/all/themes/ndep v2/docs/countryengagement/countries/NCDP Outlook Costa-Rica v4a.pdf.

OECD (n.d. $\left.{ }_{[1]}\right)$, Creditor Reporting System, OECD Paris, https://stats.oecd.org/ 
OECD (2015): Public Governance Reviews: Costa Rica: Highlights, OECD https://www.oecd.org/gov/bycountry/costarica/costa-rica-highlights.pdf.

OECD (2016) OECD Economic Surveys: Costa Rica 2016: Economic Assessment OECD Publishing Paris https://doi.org/10.1787/eco surveys-cri-2016-en.

OECD (2018a) OECD Economic Surveys: Costa Rica 2018 OECD Publishing Paris https://doi.org/10.1787/eco surveys-cri-2018-en.

OECD (2018b), "2018 Survey on Amounts Mobilised from the Private Sector by Development Finance Interventions", OECD International Development Statistics (database), OECD Paris, http://www.oecd.org/dac/financing-sustainabledevelopment/development-finance-standards/mobilisation.htm

OECD (n.d.), "Creditor Reporting System: Aid activities", OECD International Development Statistics (database), OECD Paris, https://doi.org/10.1787/data-00061-en,

Transparency International (2018): Corruption Perception Index 2017: Cosa Rica, https://www.transparency.org/news/feature/corruption_perceptions_index_2017.

United Nations (2015), Human Development Index of Costa Rica, United Nations New York retrieved from country economy (website) https://countryeconomy.com/hdi/costarica.

World Bank (2016). Doing Business Economy Profile 2017: Costa Rica. World Bank, Washington, DC. https://openknowledge.worldbank.org/handle/10986/25500.

World Bank (2017) World Bank Statistics. World Bank, Washington DC. https://data.worldbank.org/indicator/BX.TRF.PWKR.CD?end=2017\&start=1960.

World Bank (2018): Doing Business in Costa Rica 2018, World Bank, Washington, DC.http://www.doingbusiness.org/ /media/WBG/DoingBusiness/Documents/Profiles/Co untry/CRI.pdf.

World Economic Forum (2018): Country Profile: Costa Rica, http://www3.weforum.org/docs/gcr/2015-2016/CRI.pdf. 


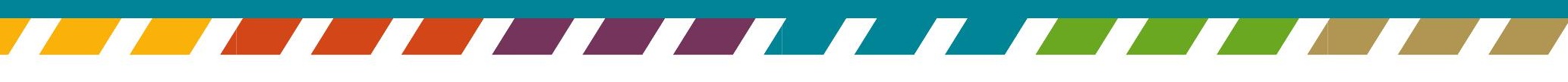

